University of Tennessee Health Science Center

UTHSC Digital Commons

$5-2009$

\title{
Effect of Methamphetamine on Gingival Fibroblast Production of Matrix Metalloproteinase (MMP)-2 and -9 and Tissue Inhibitor of Metalloproteinase (TIMP)-1 and -2 In Vitro
}

Owais Ali Farooqi

University of Tennessee Health Science Center

Follow this and additional works at: https://dc.uthsc.edu/dissertations

Part of the Periodontics and Periodontology Commons

\section{Recommended Citation}

Farooqi, Owais Ali , "Effect of Methamphetamine on Gingival Fibroblast Production of Matrix Metalloproteinase (MMP)-2 and -9 and Tissue Inhibitor of Metalloproteinase (TIMP)-1 and -2 In Vitro" (2009). Theses and Dissertations (ETD). Paper 84. http://dx.doi.org/10.21007/etd.cghs.2009.0090. 


\title{
Effect of Methamphetamine on Gingival Fibroblast Production of Matrix Metalloproteinase (MMP)-2 and -9 and Tissue Inhibitor of Metalloproteinase (TIMP)-1 and -2 In Vitro
}

\begin{abstract}
Methamphetamine (METH) abuse is associated with "METH mouth" characterized by rampant caries and periodontitis. Matrix metalloproteinases (MMPs) produced by gingival fibroblasts degrade the extracellular matrix (ECM) and play an important role in periodontitis and oral cancer metastasis. There is no information on effects of METH on fibroblast MMP production, or its role in periodontitis or tumor metastasis.

Objective: Determine effect of METH on gingival fibroblast MMP production and activity.

Methods: A human gingival fibroblast cell line was used. METH cytotoxicity was determined by measuring its effects on activity of a mitochondrial enzyme. Cells were cultured \pm METH $\left(1 \times 10^{-6}-\geq 1 \times 10^{-3} \mathrm{M}\right)$; MMP-2, MMP-9, TIMP-1,TIMP-2 and MMP:TIMP complexes in cell supernatants were measured by ELISA. MMP-2 activity was measured using the MMP-2 Biotrak Activity Assay System. Data were analyzed using ANOVA and Scheffe's $F$ procedure for post hoc comparisons.

Results: There was no significant cytotoxicity of METH at concentrations $\leq 1 \mathrm{mM}$. METH $>1 \mathrm{mM}$ caused complete loss of viability. MMP-2, TIMP-1, -2 and MMP-2:TIMP complexes were produced constitutively; MMP-9 and MMP-9:TIMP complexes were not expressed. Approximately $25 \%$ of MMP-2 was complexed with TIMP-1 or TIMP-2. METH had no significant effect on any molecules expressed constitutively or on complexed MMP-2, and it did not induce MMP-9 or MMP-9:TIMP complexes. $1 \times 10^{-5} \mathrm{M}$ METH increased total MMP-2 activity $(p=0.01)$ and APMA-activated MMP-2 activity attributable to pro-MMP-2 $(p=0.03)$. METH had no effect on endogenous active MMP-2. Using pro-MMP-2 (standard from MMP-2 activity kit) treated with METH \pm p-aminophenylmercuric acetate (APMA) and assayed for activity, METH directly activated MMP-2 and enhanced APMA activation of free pro-MMP-2.
\end{abstract}

Conclusions: METH may affect MMP-2 post-transcriptionally, increasing activity/activation of pro-MMP-2, rather than affecting protein levels.

\section{Document Type}

Thesis

\section{Degree Name}

Master of Dental Science (MDS)

\section{Program}

Periodontology

\section{Research Advisor}

David A. Tipton, D.D.S., Ph.D.

\section{Keywords}

Fibroblast, Matrix Metalloproteinase, Methamphetamine

\section{Subject Categories}

Dentistry | Medicine and Health Sciences | Periodontics and Periodontology

This thesis is available at UTHSC Digital Commons: https://dc.uthsc.edu/dissertations/84 
Effect of Methamphetamine on Gingival Fibroblast Production of Matrix Metalloproteinase (MMP)-2 and -9 and Tissue Inhibitor of Metalloproteinase (TIMP)-1 and -2 In Vitro

\author{
A Thesis \\ Presented for \\ The Graduate Studies Council \\ The University of Tennessee \\ Health Science Center
}

\begin{abstract}
In Partial Fulfillment
Of the Requirements for the Degree

Master of Dental Science

From The University of Tennessee
\end{abstract}

By

Owais Ali Farooqi

May 2009 
Copyright (C) 2009 by Owais Ali Farooqi

All rights reserved 


\section{ACKNOWLEDGEMENTS}

This research project would have been impossible without help and support of my research mentor Dr. David A. Tipton. I would like to thank my committee members Drs. Pradeep Adatrow, Jegdish Babu, Mustafa Dabbous and Swati Rawal who gave their valuable input and encouraged me throughout this project. I must also express my gratitude to UT Alumni who contribute to University of Tennessee College of Dentistry Alumni Endowment Fund, which funded this research endeavor. 


\begin{abstract}
Methamphetamine (METH) abuse is associated with "METH mouth" characterized by rampant caries and periodontitis. Matrix metalloproteinases (MMPs) produced by gingival fibroblasts degrade the extracellular matrix (ECM) and play an important role in periodontitis and oral cancer metastasis. There is no information on effects of METH on fibroblast MMP production, or its role in periodontitis or tumor metastasis.
\end{abstract}

Objective: Determine effect of METH on gingival fibroblast MMP production and activity.

Methods: A human gingival fibroblast cell line was used. METH cytotoxicity was determined by measuring its effects on activity of a mitochondrial enzyme. Cells were cultured \pm METH $\left(1 \times 10^{-6}-\geq 1 \times 10^{-3} \mathrm{M}\right)$; MMP-2, MMP-9, TIMP-1,TIMP-2 and MMP:TIMP complexes in cell supernatants were measured by ELISA. MMP-2 activity was measured using the MMP-2 Biotrak Activity Assay System. Data were analyzed using ANOVA and Scheffe's F procedure for post hoc comparisons.

Results: There was no significant cytotoxicity of METH at concentrations $\leq$ $1 \mathrm{mM}$. METH $>1 \mathrm{mM}$ caused complete loss of viability. MMP-2, TIMP-1, -2 and MMP2:TIMP complexes were produced constitutively; MMP-9 and MMP-9:TIMP complexes were not expressed. Approximately $25 \%$ of MMP-2 was complexed with TIMP-1 or TIMP-2. METH had no significant effect on any molecules expressed constitutively or on complexed MMP-2, and it did not induce MMP-9 or MMP-9:TIMP complexes. $1 \times 10^{-5} \mathrm{M}$ METH increased total MMP-2 activity $(\mathrm{p}=0.01)$ and APMA-activated MMP-2 activity attributable to pro-MMP-2 ( $\mathrm{p}=0.03)$. METH had no effect on endogenous active MMP2. Using pro-MMP-2 (standard from MMP-2 activity kit) treated with $\mathrm{METH} \pm \mathrm{p}-$ aminophenylmercuric acetate (APMA) and assayed for activity, METH directly activated MMP-2 and enhanced APMA activation of free pro-MMP-2.

Conclusions: METH may affect MMP-2 post-transcriptionally, increasing activity/activation of pro-MMP-2, rather than affecting protein levels. 


\section{TABLE OF CONTENTS}

CHAPTER 1. INTRODUCTION AND BACKGROUND 1

CHAPTER 2. MATERIALS AND METHODS 6

$\begin{array}{ll}\text { Human Gingival Fibroblasts } & 6\end{array}$

$\begin{array}{lr}\text { Methamphetamine } & 6\end{array}$

Determination of Cytotoxic Effects of Methamphetamine on

$\begin{array}{ll}\text { Human Gingival Fibroblasts } & 6\end{array}$

$\begin{array}{ll}\text { Determination of MMP and TIMP Production and MMP Activity } & 7\end{array}$

Determination of Direct Effect of METH \pm APMA on

$\begin{array}{ll}\text { pro-MMP-2 Activation } & 7\end{array}$

$\begin{array}{lr}\text { Statistical Analysis } & 8\end{array}$

CHAPTER 3. RESULTS 9

Cytotoxic Effects of METH on Human Gingival Fibroblasts 9

Constitutive Production of MMPs, TIMPs, and MMP:TIMP Complexes 9

Effect of METH on MMP, TIMP, and MMP-TIMP Complex Protein 9

Effects of METH on MMP-2 Activity 9

Direct Effect of METH on MMP-2 Activation and APMA-mediated

Activation

$\begin{array}{ll}\text { CHAPTER 4. DISCUSSION } & 20\end{array}$

LIST OF REFERENCES $\quad 27$

$\begin{array}{lr}\text { VITA } & 39\end{array}$ 


\section{LIST OF FIGURES}

Figure 1. Clinical Intra-oral Picture of METH User 3

Figure 2. $\quad$ Effect of METH on Gingival Fibroblast Viability 10

Figure 3. Time Course of Constitutive Production of MMP-2, MMP-9, TIMP-1, and TIMP-2

Figure 4. Time Course of Constitutive Production of MMP:TIMP

Complexes

Figure 5. Effect of METH on MMP-2, MMP-9, TIMP-1 and TIMP-2 Production

Figure 6. Effect of METH on MMP:TIMP Complex Production

Figure 7. Effect of METH on \% Total MMP-2 in MMP-2:TIMP Complexes

Figure 8. Effect of METH on Total MMP-2 Activity

Figure 9. Effect of METH on MMP-2 Activity: Endogenous Active MMP-2 and APMA-Activated Pro-MMP-2

Figure 10. Direct Effects of METH on Endogenous MMP-2 Activity and APMA-activation of Pro-MMP-2

Figure 11. Proposed Mechanism of Activation of the Pro-MMP-2:TIMP-2 


\section{CHAPTER 1. INTRODUCTION AND BACKGROUND}

Methamphetamine (METH) is a widely abused psychostimulant. Initially synthesized in 1919 during World War I, the drug was prescribed for many soldiers because of its stimulatory and performance-enhancing properties. ${ }^{1}$ It was not until 1959 , that the Food and Drug Administration (FDA) banned amphetamine-based inhalers because of their potential for abuse. Currently the prevalence of METH use is estimated at 35 million people worldwide and 10.4 million people in the United States. ${ }^{2}$ The number of young people who are abusing METH is astonishing. The 2003 National Survey on Drug Use and Health reported that 12.3 million Americans age 12 years or older have used METH at least once. ${ }^{3}$ A survey conducted by the Centers for Disease Control and Prevention found that approximately 1 in 10 high-school students had used METH. $^{4}$

METH and other amphetamine analogues are synthesized pharmcologically, by attaching a substituent (methoxy, methyl, halogen, or sulfur) to different positions on the phenyl ring of amphetamine. ${ }^{5}$ Amphetamines/METH have been used to treat depression, attention deficit disorder, narcolepsy and to promote weight loss. ${ }^{6}$ The federal Drug Enforcement Administration (DEA) currently classifies pharmaceutical-grade METH as a Schedule II stimulant drug. Some pharmaceutical products containing amphetamines approved for marketing include dextroamphetamine sulfate and a combination of dextroamphetamine and amphetamine salts. Methylphenidate hydrochloride is a piperidine derivative and is structurally similar to amphetamine; it therefore shares the same pharmacologic properties. The abused form of this drug's analogues include methylenedioxyMETH (MDMA, ecstasy), methylenedioxyamphetamine (MDA, the love pill), methylenedioxyethamphetamine (MDEA, Eve), and nonpharmaceutical grade METH (ice, crystal meth). These drug analogues cause hyperactivity, euphoria, talkativeness, hyperalertness, decreased appetite and increased physical and sexual endurance. ${ }^{3}$ Not infrequently, mild toxicity is seen in people who abuse this drug. This is characterized by headache, irritability, hypertension, headache, tachycardia, mydriasis, tremor, hyperpyrexia, and hyperreflexia. ${ }^{7}$ Overdose can lead to confusion, diaphoresis, palpitations, nausea, vomiting, hallucinations, convulsions, and coma. ${ }^{8,9,10,11}$ A method to treat acute overdose, at least theoretically, is acidification of the urine to increase elimination. This generally is not recommended due to risk of a weak base such as METH becoming ionized in an acidic environment potentially causing rhabdomyolysis and renal failure. ${ }^{12} \mathrm{METH}$ is an extremely addictive and a potent stimulant of the central nervous system, causing a release of norepinephrine and dopamine at the synaptic cleft while blocking their reuptake. ${ }^{13}$ This depletes neurotransmitters and may contribute to rapid tolerance and withdrawal symptoms. METH, structurally similar to epinephrine, increases both systolic and diastolic blood pressures, which is usually accompanied by reflex bradycardia. ${ }^{14}$

During a "binge", one chronic METH user can consume 8-12 g of METH in one day. ${ }^{9}$ METH can be snorted, smoked, swallowed, and injected. After oral administration, the time to maximum plasma concentration ( $t \max )$ is two to three hours, although the 
drug's effects can be felt in as little as 20 minutes. ${ }^{15}$ METH users typically progress to snorting, smoking, or injecting the drug to decrease the onset time; the $t$ max for injected, snorted, and smoked METH is $2-4$ minutes (described as the "rush"). ${ }^{16}$ METH is metabolized primarily by the liver. The drug's oxidation and glucuronidation results in a active metabolite (amphetamine) and two inactive metabolites (norephedrine and $p$ hydroxynorephedrine). The elimination half-life $\left(t^{1} / 2\right)$ of METH varies widely, depending on urine $\mathrm{pH}$. At $\mathrm{pH} 6-8$, the $t^{1 / 2}$ is approximately 12 hours and is relatively constant. ${ }^{14}$

Several case reports have been published on the effects of METH on oral tissues. The clinical picture of "METH mouth" is one of rampant caries, xerostomia and teeth with hopeless prognoses. Several factors contribute to these conditions. METH users are hyperactive and rarely stop to eat or drink anything during times of acute drug use, leading to generalized dehydration. Rather than drink water, METH users report craving sugar and typically drink large quantities of non-diet, caffeine-rich soft drinks; MountainDew is commonly mentioned as a beverage of choice. ${ }^{17}$ METH also increases sympathetic activity in the central nervous system, reducing saliva secretion by stimulation of inhibitory $\alpha 2$ receptors resulting in reductions in unstimulated salivary flow. What little saliva is produced is high in protein, thereby increasing the patient's sensation of oral dryness. ${ }^{18}$

METH abusers are frequently seen with rampant caries due to absence of protective effects of saliva. Typically the cervical areas of both maxillary and mandibular teeth are involved and lead to gross caries involvement of the entire tooth. However, METH-associated caries progresses slowly as compared to other forms of caries caused by drug- or postradiation-induced xerostomia. ${ }^{11} \mathrm{METH}$ itself is acidic due to its chemical formulation and therefore when smoked, the enamel breakdown could possibly occur. However a study by Navarro et al. showed that high levels of MDMA detected in the saliva accounted for only a small decrease in salivary $\mathrm{pH}$, from 7.4 to 6.9. Because the critical $\mathrm{pH}$ at which enamel demmineralizes is 5.5 , the $\mathrm{pH}$ change caused by MDMA does not significantly contribute to caries formation. ${ }^{19}$ METH causes restlessness, anxiety, irritability, fatigue, and dysphoria. Tooth wear (bruxism) is very common in these patients. ${ }^{20}$ During times of acute use, users tend to grind and clench their jaws, further contributing to tooth wear. ${ }^{21}$ While a typical pattern of gross caries is often seen in METH user, these patients can also exhibit significant gingival and periodontal inflammation and destruction (Figure 1).

In periodontal tissue destruction as well as metastasis of oral cancer, a family of zinc-dependent endopeptidases called matrix metalloproteinases (MMPs) are suggested to play an important role. ${ }^{22,23}$ Inflammation of the periodontal tissues leads to connective tissue degradation and tooth loss. Analysis of gingival crevicular fluid has shown the presence of MMPs such as collagenase and gelatinase that, in the acute stages of periodontitis, come mainly from polymorphonuclear leukocytes. These active forms of these enzymes in gingival crevicular fluid or mouthrinse samples correlate with tissue destruction and, therefore, provide a sensitive method to demonstrate disease activity. ${ }^{24}$ MMPs are able to degrade the components of periodontal extracellular matrix (ECM) and fall into three major groups: the interstitial collagenases, the gelatinases and 


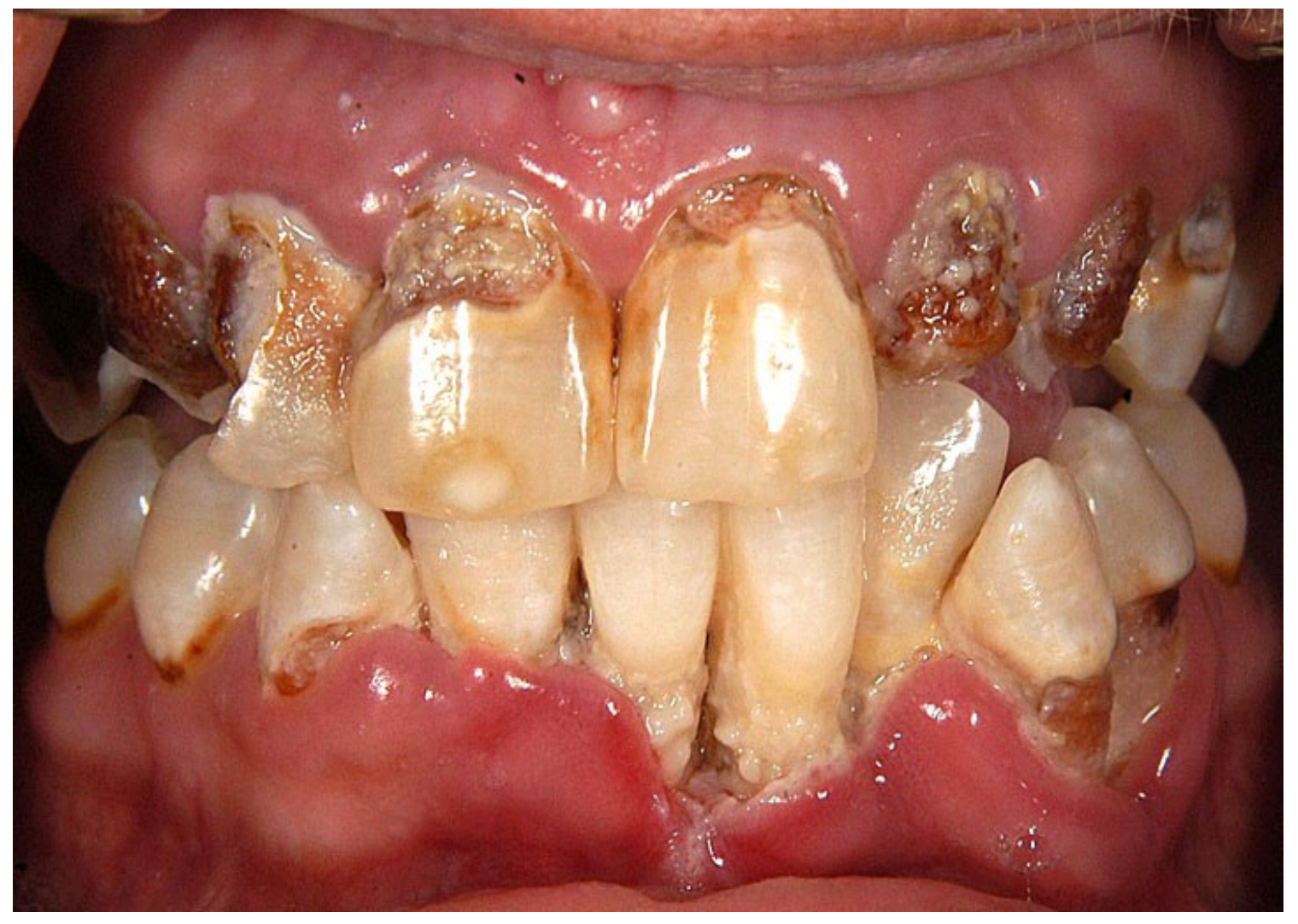

Figure 1. Clinical Intra-oral Picture of METH User.

Reprinted with permission. Wagner S. Methamphetamine use and oral health. http://www.ada.org/public/topics/methmouth.asp. (accessed 2009 March 12) ${ }^{25}$ 
the stromelysins. The interstitial collagenases (MMP-1, -8 and -13) cleave interstitial collagens. The gelatinases (MMP-2 and -9) degrade types IV, V, VII, X and XI collagens as well as fibronectin, elastases and aggrecan. The gelatinases act synergistically with collagenases by degrading denatured collagens (gelatins). The stromelysins including MMP-3 have broader specificity and can degrade non-triple helical regions of native collagen II, III, IV, V, IX, X, XI and proforms of MMPs as well as proteoglycans and matrix glycoproteins. Other MMPs not in these groups include matrilysin, metalloelastase and membrane-bound metalloproteinase (MT-MMPs).

MMPs are secreted in a latent pro-enzyme form, their activation involves the loss of the propeptide. The proteolytic activity of MMPs is under control of several factors including endogenous specific inhibitors, the tissue inhibitors of metalloproteinases (TIMPs). The balance between tissue inhibitors of metalloproteinases TIMPs and activated MMPs affects the ECM remodeling and tissue breakdown in periodontitis. TIMP-1, a 30-kDa glycoprotein is considered the major inhibitor while TIMP-2 a nonglycosylated inhibitor, though less abundant, binds to pro-MMP-2 and is involved in controlling its activation. ${ }^{26}$ In gingival crevicular fluid of patients with periodontitis TIMP-1 and TIMP-2 levels were found to be lower than in healthy control subjects. ${ }^{27}$

The expression of MMPs may be upregulated in some pathological conditions such as inflammation and tumor invasion. In the context of oral diseases, MMPs have other significant roles in wound healing and immunity and in fibrosis. ${ }^{28,29,30,31}$ The role that has been considered of great clinical importance in periodontitis is the ability of MMPs to activate latent forms of effector proteins, such as antimicrobial peptides, chemokines, and cytokines, as well their role in altering protein function, such as shedding of cell-surface proteins. ${ }^{32}$ During wound healing and inflammation a great number of chemokines are proteolytically processed by various MMPs which leads to subsequent modifications of chemokine function. MMP-2 and MMP-9 (also known as $72 \mathrm{kDa}$ and $92 \mathrm{kDa}$ type IV collagenases or gelatinase A and gelatinase $\mathrm{B}$, respectively) are known to be upregulated in periodontitis patients. ${ }^{33,34,35}$ MMP-2 and MMP-9 are also associated with the malignant phenotype of tumor cells due to their ability to degrade type IV collagen, a major component of basement membranes. ${ }^{36}$ Elevated MMP-2 and MMP-9 activities are important in metastatic cancers such as ovarian carcinoma and oral cancers. ${ }^{37,38,39}$

Current literature searches show no published studies on the effects of METH on specific oral tissue cells and their activities. A recent study showed that repeated METH treatment induced behavioral sensitization, which was accompanied by an increase in MMP-2/-9/TIMP-2 activity in the brain. ${ }^{40}$ However the effect of METH on gingival fibroblast MMP production, activity and regulation are unknown. Up-regulation of gingival fibroblast MMP activity by METH could contribute to the severity of periodontal destruction and/or tumor metastasis in METH users. In addition, cytotoxic effects of METH on gingival fibroblasts could compromise the ability of these cells to repair damaged periodontal tissue. 
The overall purpose of this project was to examine the effects of METH on human gingival fibroblasts. The hypothesis tested was that METH contributes to gingival and periodontal breakdown via cytotoxic effects on gingival fibroblasts and by altering the balance between MMPs and TIMPS, specifically by increasing the amounts and/or activity of MMP-2 and/or MMP-9, and by decreasing the levels of TIMP-1 and/or TIMP-2.

The hypothesis was tested by accomplishing the following specific aims:

- Specific Aim 1: Measure constitutive enzyme activity and production of MMP-2 and MMP-9; TIMP-1 and TIMP-2; and MMP:TIMP complexes by human gingival fibroblasts in vitro.

- Specific Aim 2: Measure the effect of METH on cell viability, enzyme activity and on production of MMP-2, MMP-9, TIMP-1, TIMP-2 and MMP:TIMP complexes by human gingival fibroblasts in vitro. 


\section{CHAPTER 2. MATERIALS AND METHODS}

\section{Human Gingival Fibroblasts}

Normal human gingival fibroblast cell lines, previously established and available for the study, were used in this work. The cell lines were established from gingival explants using standard techniques. The gingival explants were minced using a scalpel and then washed with Dulbecco's Modified Eagle Medium (DMEM; Gibco; Grant Island, NY) supplemented with 10\% (v/v) newborn calf serum (NCS; Gibco) and $100 \mu \mathrm{g} / \mathrm{ml}$ gentamicin (Sigma Chemical Co.; St Louis, MO) (complete medium), supplemented with $2.5 \mu \mathrm{g} / \mathrm{ml}$ amphotericin B (Sigma), $100 \mathrm{U} / \mathrm{ml}$ penicillin (Sigma) and $100 \mu \mathrm{g} / \mathrm{ml}$ streptomycin. The tissue pieces were placed in $25 \mathrm{~cm}^{2}$ flasks, allowed to adhere, and then incubated in complete medium at $37^{\circ} \mathrm{C}$ in a humidified atmosphere of $5 \% \mathrm{CO}_{2}$ in air until outgrowth of fibroblasts occurred (within two weeks). At the point of confluency in the $25 \mathrm{~cm}^{2}$ flasks, the cells were removed from the flasks by a brief ( $5 \mathrm{~min}$ ) treatment with trypsin ( $0.25 \%$; Gibco), transferred to $75 \mathrm{~cm}^{2}$ flasks, and routinely cultured in complete medium. Cells between passages five and fourteen were used in the experiments.

\section{Methamphetamine}

Methamphetamine $\mathrm{HCl}$ solution $\left[1 \mathrm{mg} / \mathrm{ml}\left(5.4 \times 10^{-3} \mathrm{M}\right)\right.$ in methanol] and methamphetamine hydrochloride powder were purchased from Sigma. Methamphetamine hydrochloride powder is soluble in water.

\section{Determination of Cytotoxic Effects of Methamphetamine on Human Gingival Fibroblasts}

In order to determine the proper, non-cytotoxic doses of METH for experimental use, the effects of the drug on cell viability were measured. This was assessed by determining its effect on the ability of the cells to cleave the tetrazolium salt $(3-[4,5-$ dimethylthiazol-2-yl]-2,5-diphenyl tetrazolium bromide) (MTT) to a formazan dye, using a kit from Boehringer Mannheim Corp. (Indianapolis, IN). Individual wells of 96-well microtiter tissue culture plates were seeded with $2.5 \times 10^{4}$ cells in $0.2 \mathrm{ml}$ of complete medium. The cells were incubated overnight at $37^{\circ} \mathrm{C}$. The medium was then removed and replaced with DMEM containing $100 \mu \mathrm{g} / \mathrm{ml}$ gentamicin( DMEM-gent \pm METH $(25 \mathrm{mM}$ to $\left.1 \times 10^{-12} \mathrm{M}\right)$. $100 \mathrm{x}$ METH stock solutions were made in methanol [or water for higher concentrations to which the cells were exposed $\left.\left(>5 \times 10^{-5} \mathrm{M}\right)\right]$ and then diluted 1:100 in tissue culture medium. It has been determined in this laboratory that methanol at $1 \%$ is not toxic to gingival fibroblasts. After 6 days, MTT was added to the cells at a final concentration of $0.5 \mathrm{mg} / \mathrm{ml}$ and incubated for $4 \mathrm{hr}$ at $37^{\circ} \mathrm{C}$. Purple formazan crystals produced from the MTT by metabolically active cells were solubilized by overnight exposure to a solubilization solution provided in the kit, at $37^{\circ} \mathrm{C}$. Absorbance was read at 
$540 \mathrm{~nm}$ using a microtiter plate spectrophotometer. Results were expressed as \% control ( $\mathrm{A}_{540 \mathrm{~nm}}$ in cells exposed to DMEM-gent only).

\section{Determination of MMP and TIMP Production and MMP Activity}

To obtain conditioned media for the assays, cells ( $7.5 \times 10^{4} /$ well in 24 -well plates) were exposed to serum-free (SF) DMEM-gent or SF DMEM-gent containing METH $\left(1 \times 10^{-3} \mathrm{M}-1 \times 10^{-6} \mathrm{M}\right) .100 \times \mathrm{METH}$ stock solutions were made in methanol [or water for higher concentrations to which the cells were exposed $\left.\left(>5 \times 10^{-5} \mathrm{M}\right)\right]$ and then diluted 1:100 in DMEM-gent. Cell supernatant fluids were harvested at days 1-6. Production of MMP and TIMP protein was measured in these samples using enzyme-linked immunosorbent assay (ELISA) kits from R\&D Systems (Minneapolis MN). Protein levels of MMP-2 or MMP-9 complexed with TIMP-1 or TIMP-2 were measured using specific ELISA (R\&D). For the ELISAs, absorbance values were read at using a microtiter plate spectrophotometer, and the results were expressed as the amount of

protein or activity per mg protein in the conditioned media or in the cell monolayer. ${ }^{41,42}$

Activity of MMP-2 was measured using the MMP-2 Biotrak Activity Assay System (GE Healthcare; Piscataway NJ). The assay uses the pro form of a detection enzyme that can be activated by captured active MMP-2, into an active detection enzyme, through a single proteolytic event. The natural activation sequence in the pro detection enzyme has been replaced using protein engineering, with an artificial sequence recognized by specific matrix metalloproteinases. MMP-activated detection enzyme can then be measured using a specific chromogenic peptide substrate. Standards and samples were incubated in microplate wells precoated with anti-MMP-2 antibody. Any MMP-2 present bound to the wells, other components of the sample being removed by washing and aspiration. Either the endogenous levels of active MMP-2, or the total levels of MMP-2 in a sample, were detected. In order to measure the total MMP-2 content (endogenous active + pro-MMP-2), any bound MMP-2 in its pro form is activated using p-aminophenylmercuric acetate (APMA). The standard is pro MMP-2 which is activated in parallel for both types of sample. Endogenous active MMP-2 was detected in samples without APMA treatment. The level of pro-MMP-2 activity was determined by subtraction (total activity - endogenous activity). Color development was read at $405 \mathrm{~nm}$ in a microplate spectrophotometer. MMP-2 activity is directly proportional to the generation of color through the cleavage of the substrate used in this kit, it can be represented by the rate of change of absorbance at $405 \mathrm{~nm}$. i.e $\delta \mathrm{Abs}_{405} / \mathrm{h}^{2} \times 1000$, where $\mathrm{h}$ is the incubation time in hours.

\section{Determination of Direct Effect of METH \pm APMA on pro-MMP-2 Activation}

In these assays, the pro-MMP-2 standard ( $6 \mathrm{ng} / \mathrm{ml}$ solution) was used. Samples were incubated with or without APMA, or with METH $\left(1 \times 10^{-6} \mathrm{M}-2.5 \mathrm{mM}\right) \pm$ APMA. The MMP-2 Biotrak Activity Assay System was used to assess effects of these treatments on activation of pro-MMP-2, as described above. 


\section{Statistical Analysis}

All experiments were performed with triplicate samples. The data were expressed as mean \pm standard deviation and were analyzed using a one-way analysis of variance (ANOVA) and Scheffe's F procedure for post hoc comparisons, using StatView ${ }^{\circledR}$ software. 


\section{CHAPTER 3. RESULTS}

\section{Cytotoxic Effects of METH on Human Gingival Fibroblasts}

Cytotoxic effects of METH on the fibroblasts were determined using the MTT assay, which measures the ability of the cells to cleave the tetrazolium salt MTT to a formazan dye. The results were expressed as percent of control $\left(\mathrm{A}_{540}\right.$ in cells exposed to DMEM-gent containing 1\% methanol). Previous work showed that $1 \%$ methanol is not toxic to these gingival fibroblasts (data not shown). Figure 2 shows that there was no significant cytotoxicity of METH at concentrations $\leq 1 \mathrm{mM}$ after 6-day exposure. Concentrations of METH $>1 \mathrm{mM}$ caused complete loss of viability.

\section{Constitutive Production of MMPs, TIMPs, and MMP:TIMP Complexes}

In initial experiments, the cells were exposed to DMEM-gent containing $1 \%$ methanol (diluent for $[\mathrm{METH}] \leq 1 \times 10^{-5} \mathrm{M}$ ) for incubation times of $1,2,3,4$, and 6 days. [Preliminary experiments showed that $1 \%$ methanol had no effect on cell viability or production of MMPs or TIMPs (data not shown)]. Figures 3 and 4 show that there was a time-dependent increase in constitutive production of all molecules assayed (except MMP-9 and MMP-9/TIMP complexes, which were not expressed). TIMP-1 was produced in greater amounts than TIMP-2 (Figure 3). Figure 4 shows that MMP-2:TIMP complexes were produced constitutively $(2: 2>2: 1)$. Approximately $25 \% \mathrm{MMP}-2$ was complexed with TIMP-1 or TIMP-2 under these conditions (data not shown).

\section{Effect of METH on MMP, TIMP, and MMP-TIMP Complex Protein}

In experiments testing the effects of METH on the production of MMPs, TIMPs, and MMP:TIMP complexes, a 4-day incubation period was used, based on the experiments described above. Figure 5 shows that there was no significant effect of METH on levels of MMP-2, TIMP-1 or TIMP-2. Similarly, METH had no effect on MMP-2:TIMP complexes, and exposure to METH did not induce the fibroblasts to produce detectable protein levels of MMP-9 or MMP-9/TIMP complexes (Figures 5 and 6). There was no significant effect of METH on the percent of MMP-2 complexed with TIMP-1 or TIMP-2 (Figure 7).

\section{Effects of METH on MMP-2 Activity}

Figure 8 shows constitutive levels of total MMP-2 activity, and the effects of METH. METH $\left(1 \times 10^{-5} \mathrm{M}\right)$ significantly increased total (endogenous active + APMAactivated) MMP-2 activity. At this concentration total MMP-2 activity was increased $\sim 50 \%$, compared to control $(\mathrm{p}=0.01)$. When exposed to $1 \times 10^{-4} \mathrm{M} \mathrm{METH}$, there was a decrease in total activity of $\sim 25 \%(\mathrm{p}=0.02)$. 


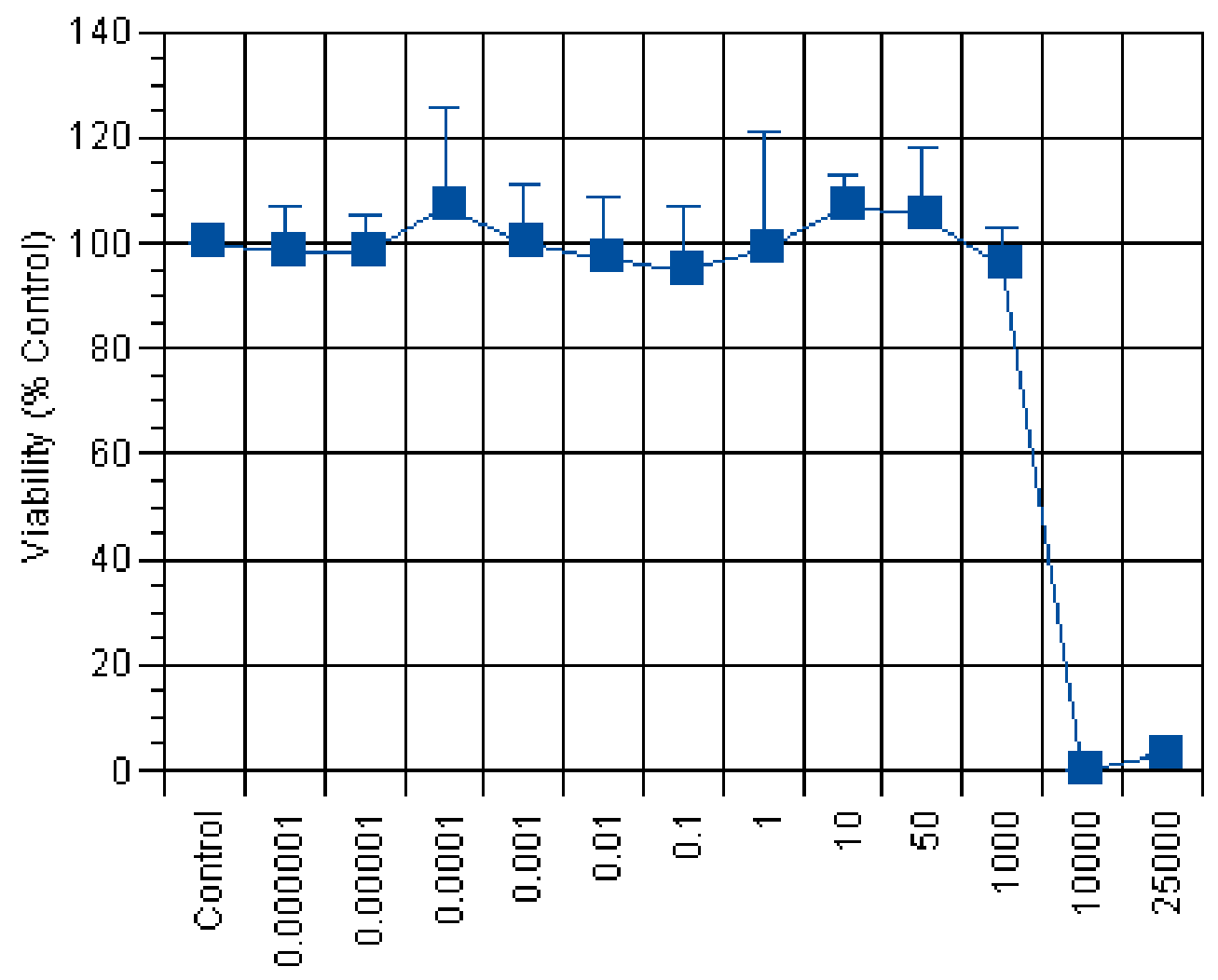

Methamphetamine (uM)

Figure 2. Effect of METH on Gingival Fibroblast Viability 


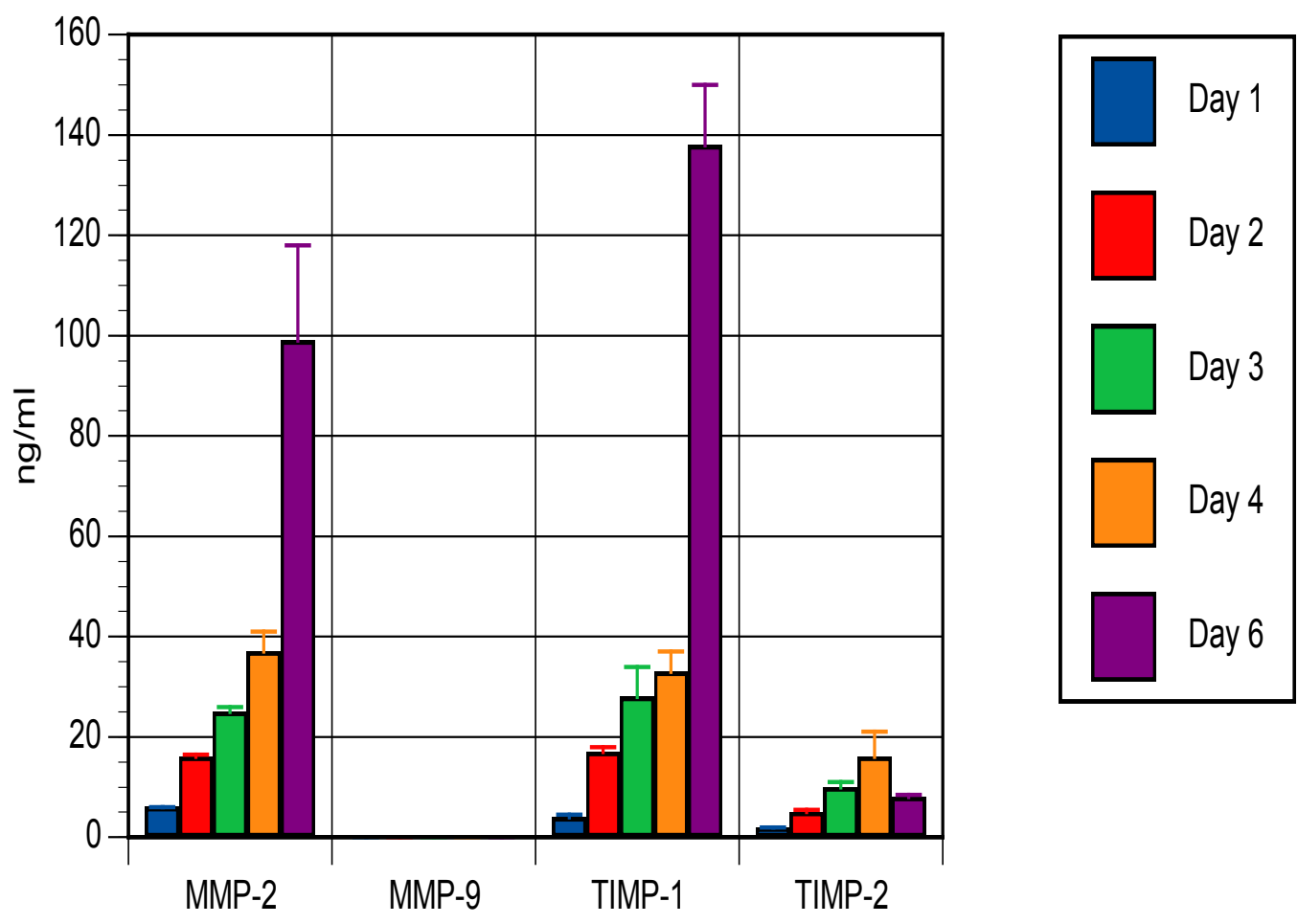

Figure 3. Time Course of Constitutive Production of MMP-2, MMP-9, TIMP-1, and TIMP-2 


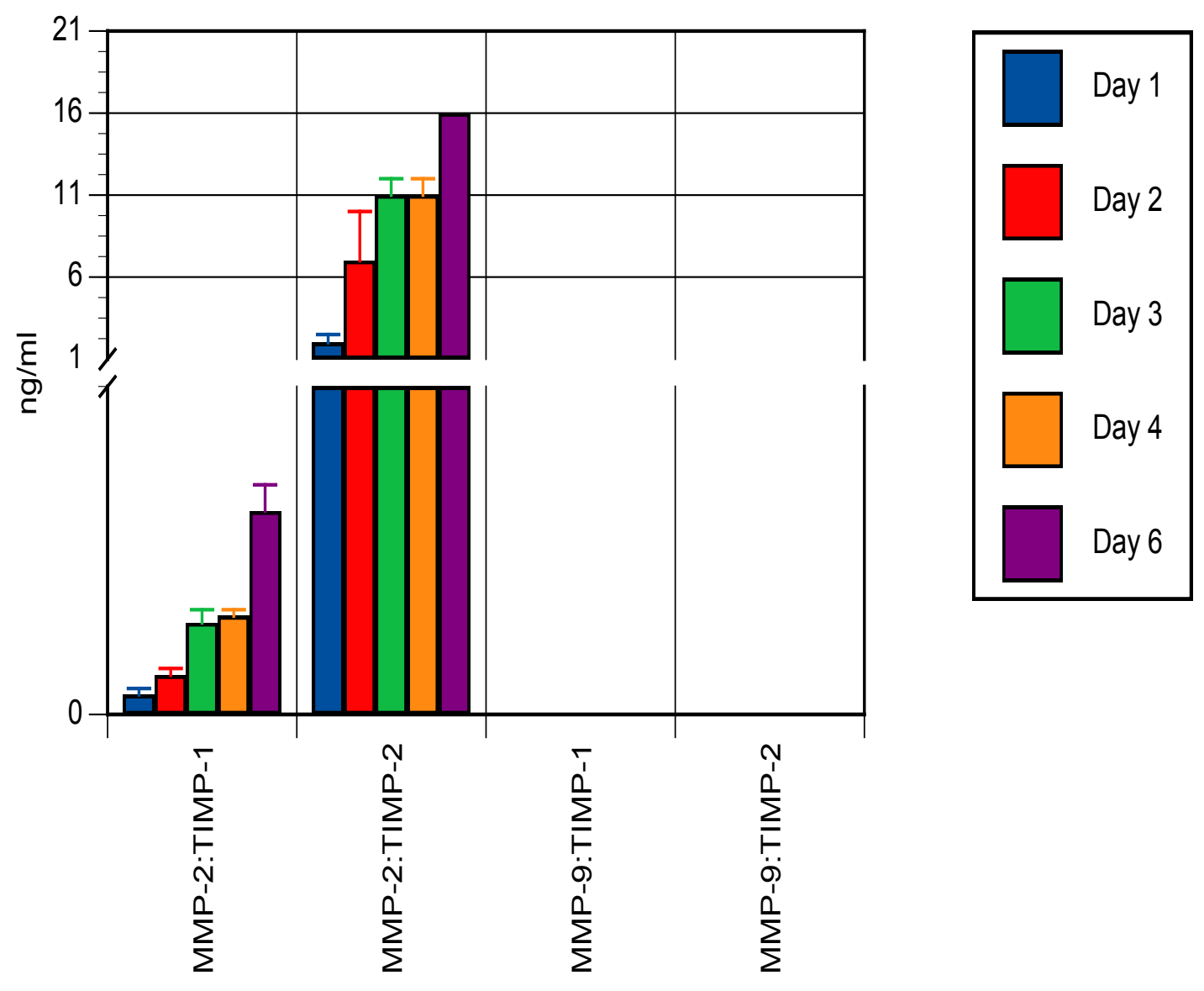

Figure 4. Time Course of Constitutive Production of MMP:TIMP Complexes 


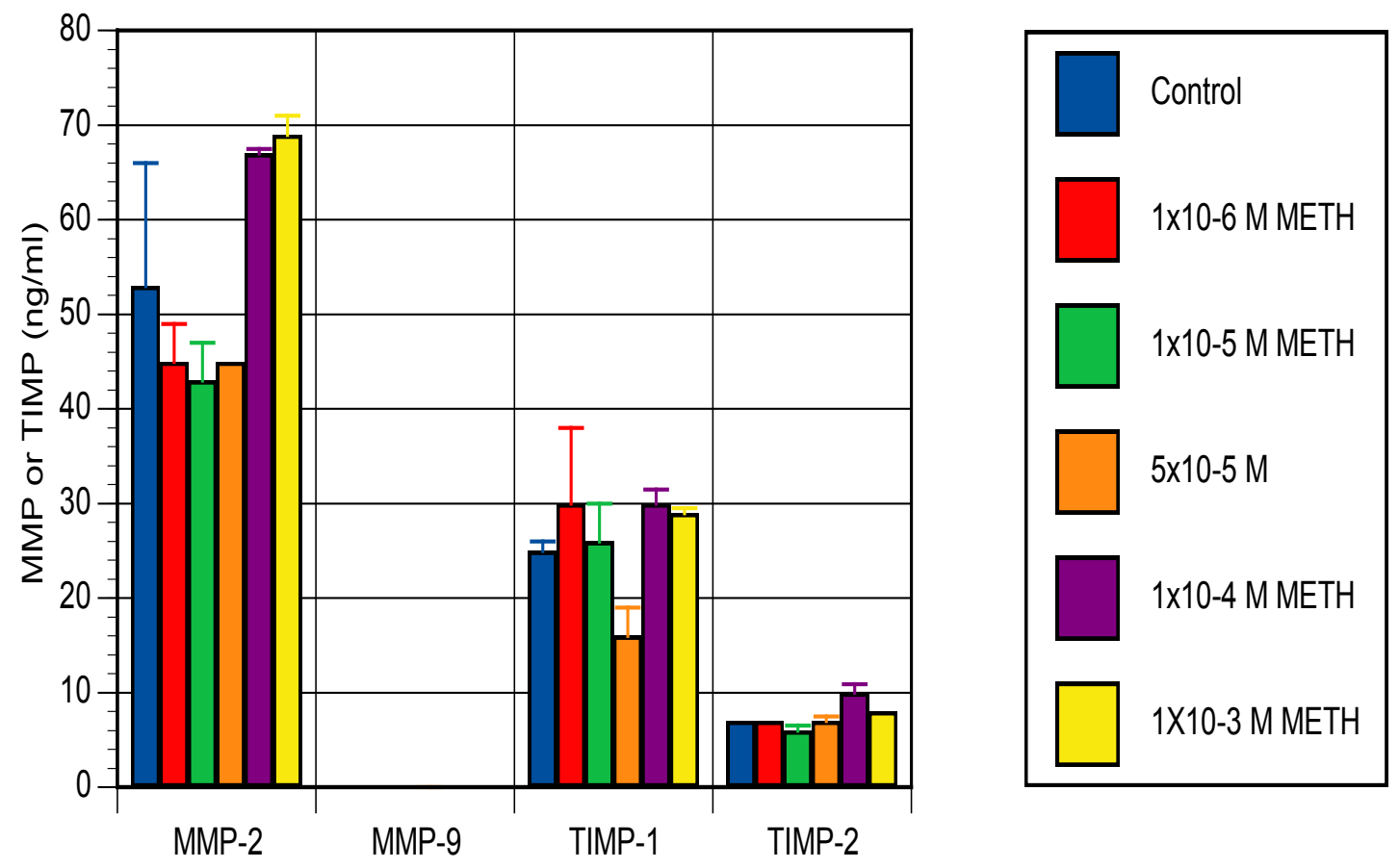

Figure 5. Effect of METH on MMP-2, MMP-9, TIMP-1, and TIMP-2 Production 


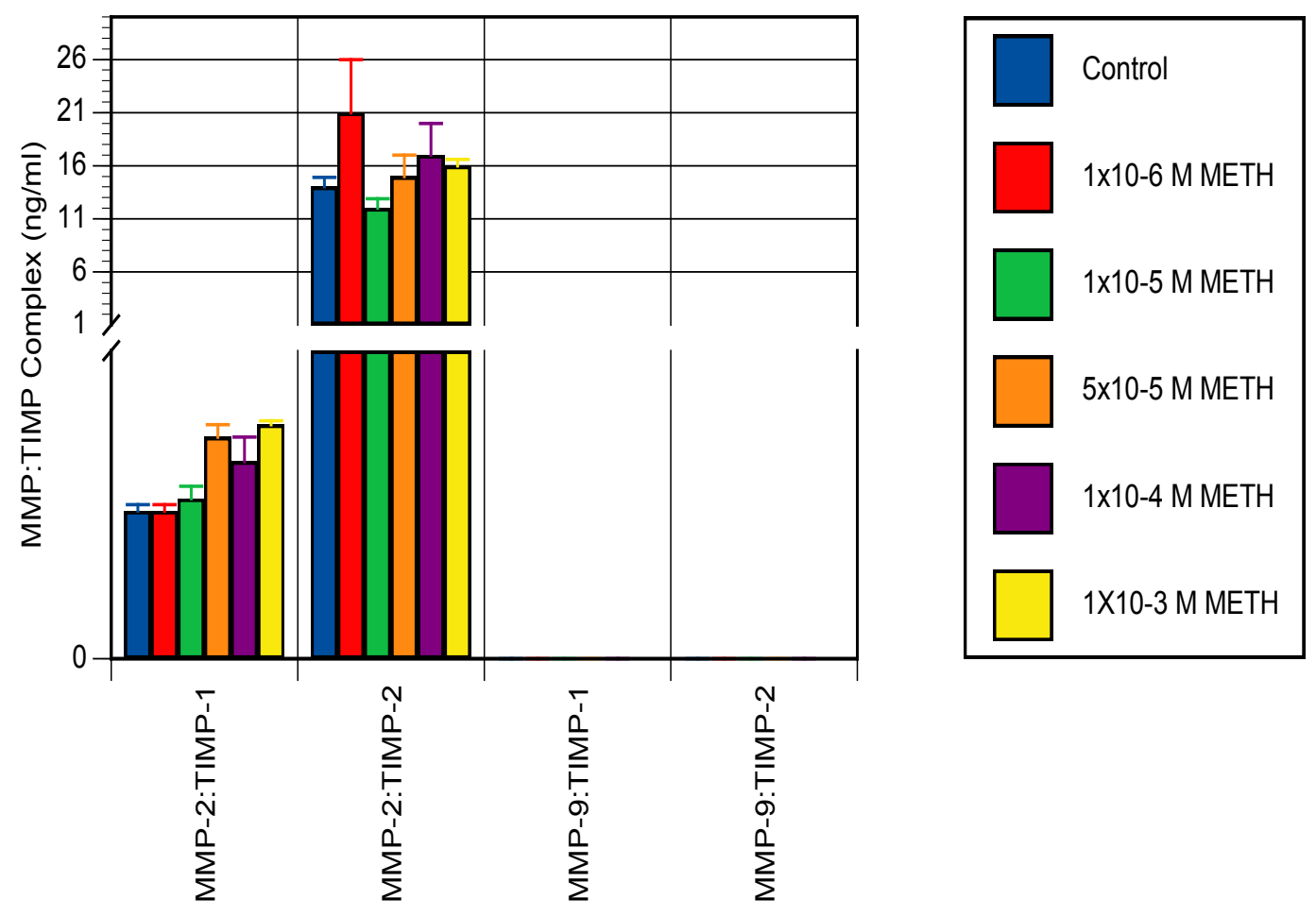

Figure 6. Effect of METH on MMP:TIMP Complex Production 

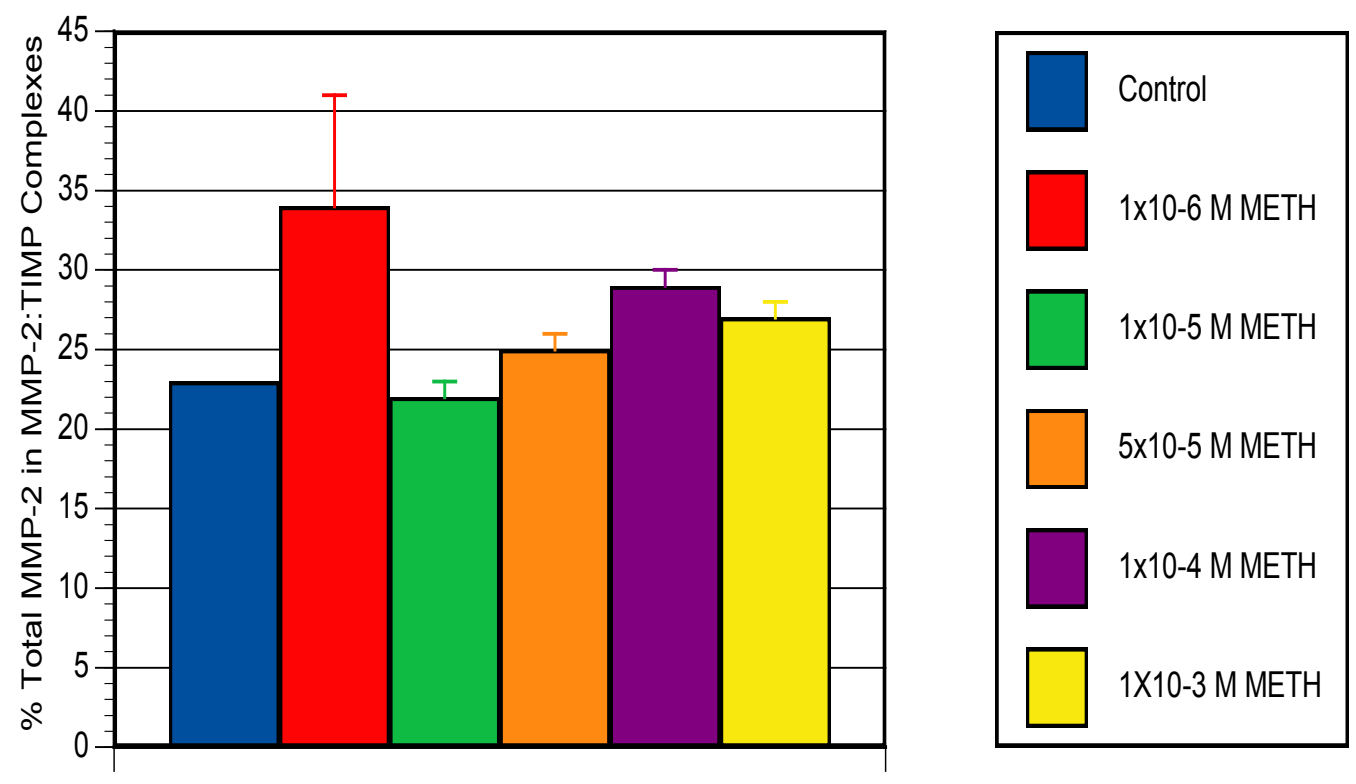

Figure 7. Effect of METH on \% Total MMP-2 in MMP-2:TIMP Complexes 


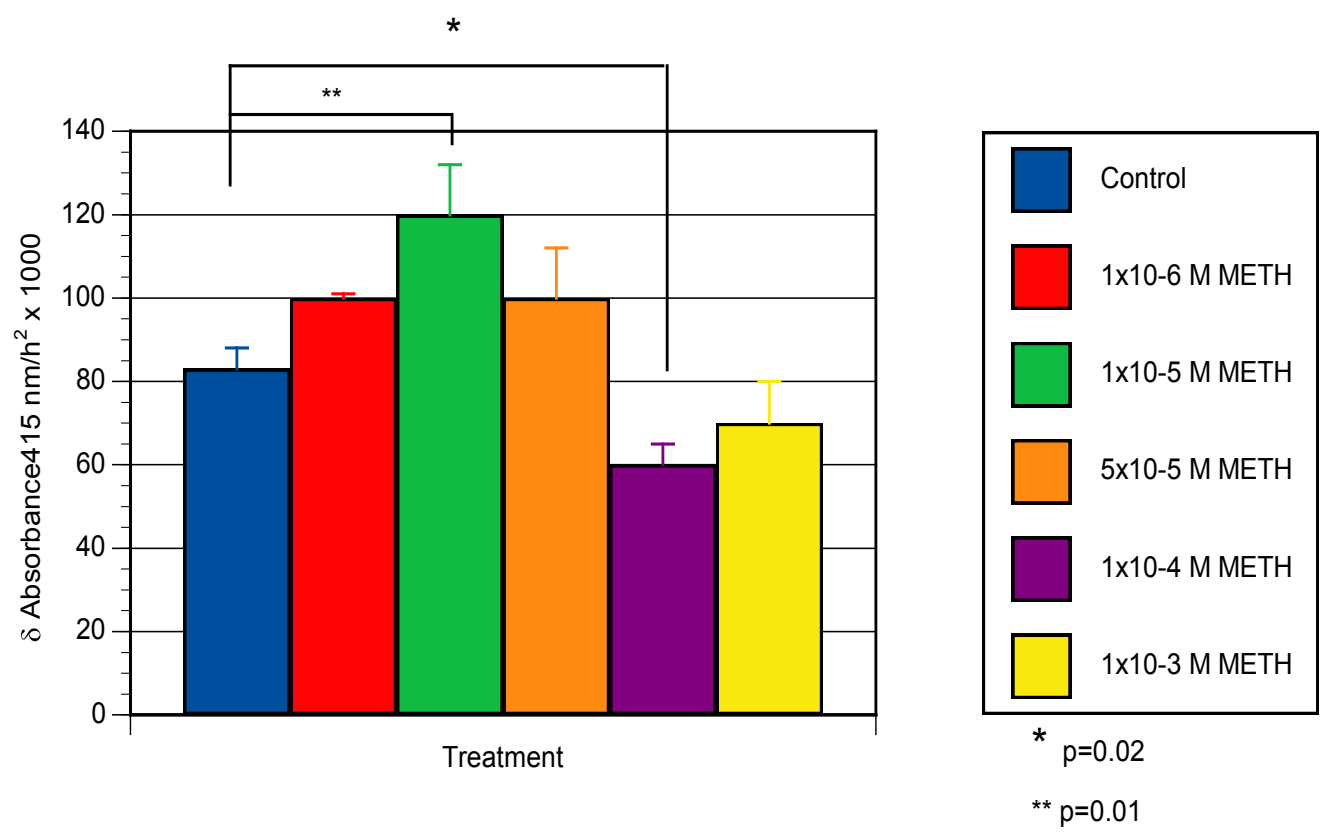

Figure 8. Effect of METH on Total MMP-2 Activity 
METH $\left(1 \times 10^{-5} \mathrm{M}\right)$ significantly increased APMA-activated MMP-2 activity attributable to pro-MMP-2 $(p=0.03)$ (Figure 9). When exposed to $1 \times 10^{-4} \mathrm{M}$ METH, there was a decrease in APMA-activated MMP-2 activity attributable to pro-MMP-2 that was not statistically significant. There was little or no effect of METH on endogenous active ?MMP-2 (Figure 9).

\section{Direct Effect of METH on MMP-2 Activation and APMA-mediated Activation}

Total MMP-2 protein (as well as TIMPS, MMP/TIMP complexes and \% complexed MMP-2) were not significantly affected by METH, yet MMP-2 activity was increased by exposure to METH. In order to determine whether METH directly activated MMP-2 or enhanced APMA activation, pro-MMP-2 (6 ng/ml standard from MMP-2 activity kit) was treated with $\mathrm{METH} \pm \mathrm{APMA}$ and assayed for activity. Figure 10 shows that METH may directly activate MMP-2 and enhance APMA activation of free proMMP-2. 


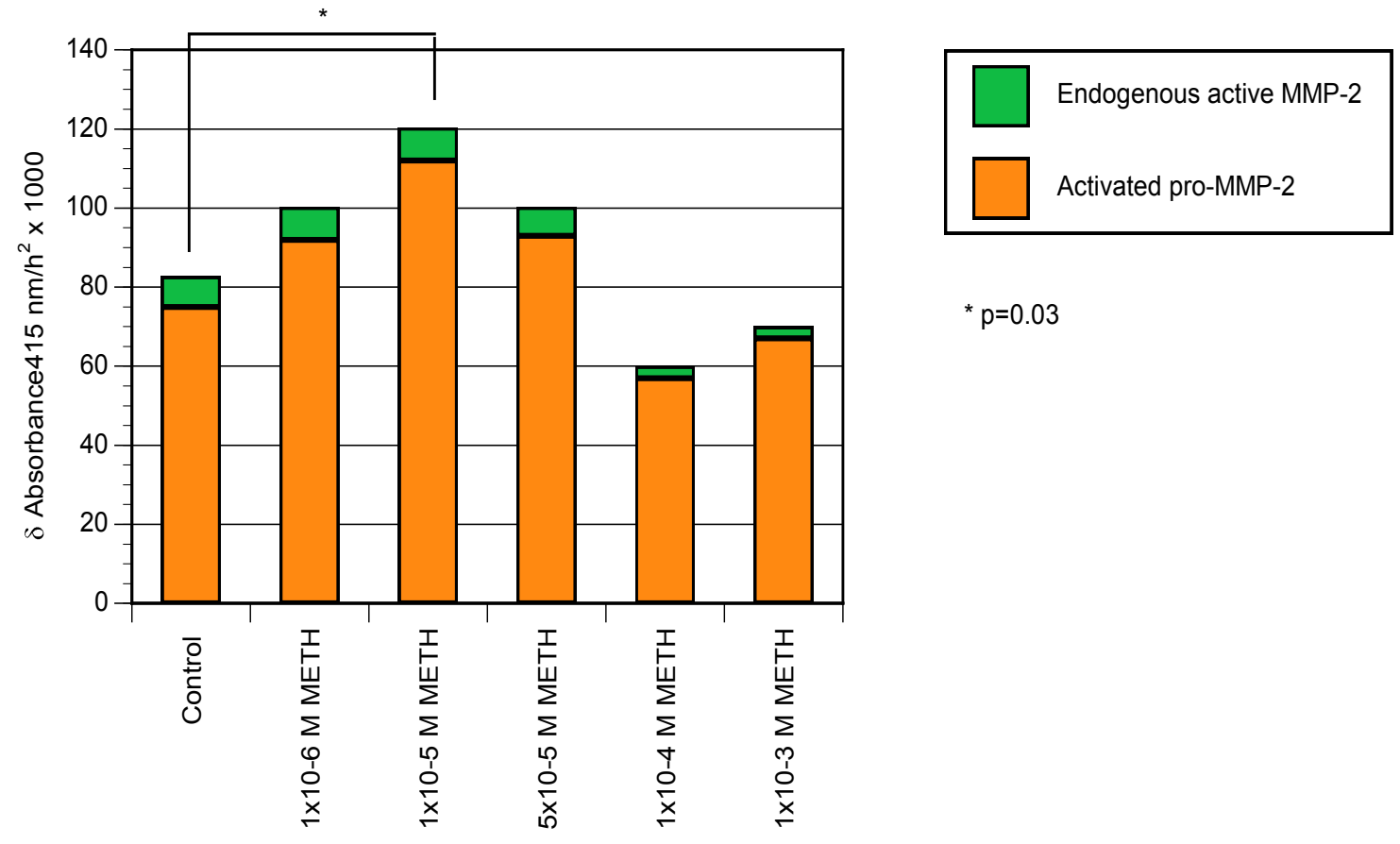

Figure 9. Effect of METH on MMP-2 Activity: Endogenous Active MMP-2 and APMAActivated Pro-MMP-2 


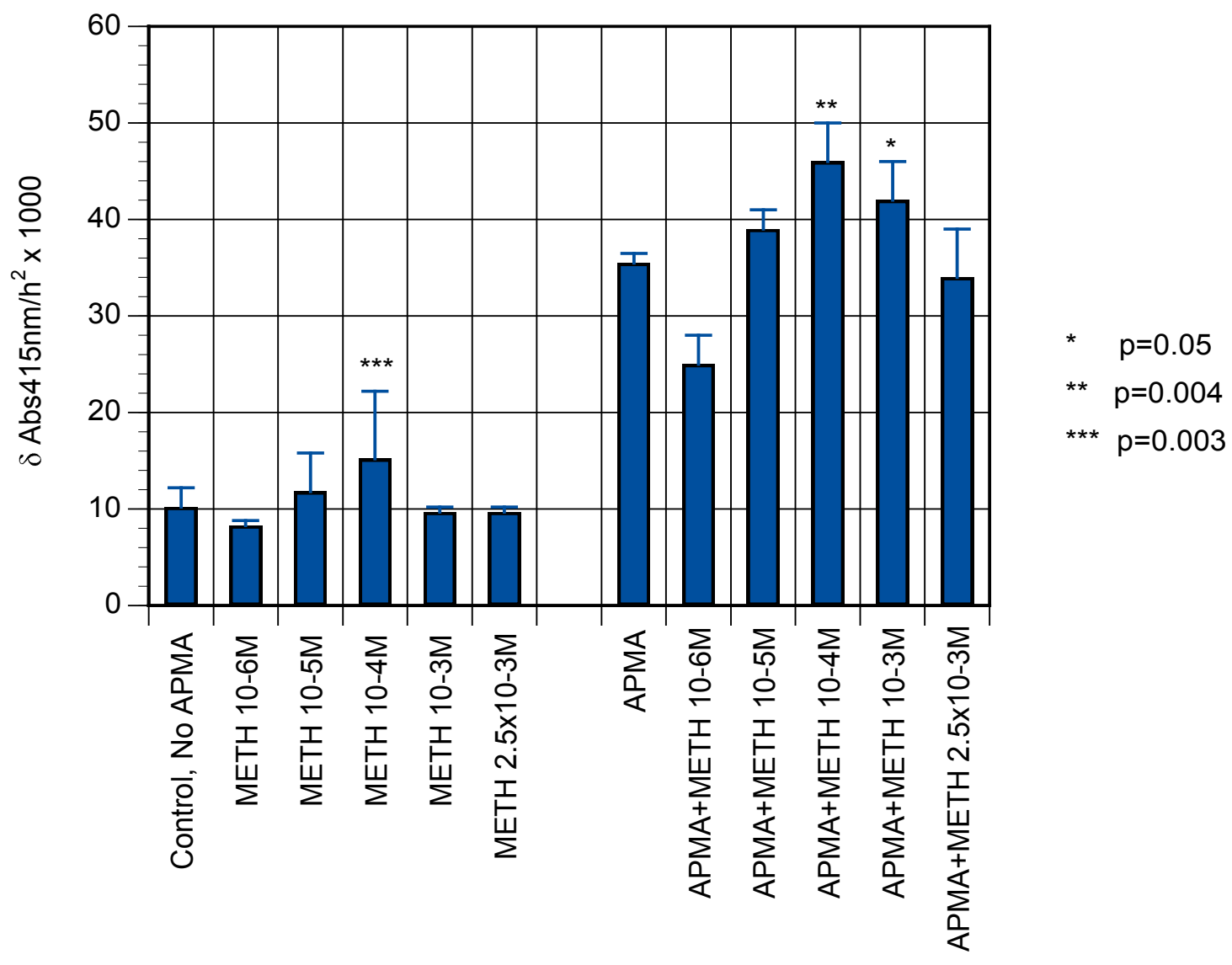

Figure 10. Direct Effects of METH on Endogenous MMP-2 Activity and APMA-activation of Pro-MMP-2 


\section{CHAPTER 4. DISCUSSION}

Previous case reports of the adverse effects of METH on oral tissues have principally focused on teeth. This study attempted to determine the effects of this drug on soft tissue (gingiva) at the cellular level, specifically the production and activity of two MMPs that play a role in both periodontal destruction and tumor invasion.

Using an assay that measured the ability of the cells to cleave a tetrazolium salt MTT to a formazan dye, it was found that concentrations of METH $\leq 1 \mathrm{mM}$ caused no cytotoxicity to human gingival fibroblasts after 144 hours of exposure. METH at $>1$ $\mathrm{mM}$ caused complete toxicity and cell death. This is consistent with the results of studies using other cell types. Israeli et al. found that $\mathrm{METH} \geq 1 \mathrm{mM}$ was toxic to mouse monoaminergic cells, and Deng et al. showed that $2 \mathrm{mM}$ METH killed a minimum of $50 \%$ of rat striatal cells after 24 -hr exposure. ${ }^{43,44}$ Another study by Genc et al. found that $\mathrm{METH}>0.1 \mathrm{mM}$ was toxic to rat oligodendrocytes (the myelin-forming cells in the central nervous system), and that by $72 \mathrm{hr}$, toxic METH concentrations caused $90 \%$ cell death. ${ }^{45}$ Oligodendrocytes were therefore somewhat more sensitive to METH than the human gingival fibroblasts used in the present study. Another study from this laboratory suggested that the human monocyte cell line THP-1 is also more sensitive to METH than human gingival fibroblasts. ${ }^{46}$ Only one METH exposure period (144 hr) was tested in this study, but the finding that there was $>90 \%$ toxicity caused by METH concentrations $>1$ $\mathrm{mM}$ is consistent with the study by Genc et al., cited above. While METH levels in humans have been measured in plasma and saliva at $0.2 \mu \mathrm{M}$ and $2 \mu \mathrm{M}$, respectively, because of METH's high bioavailability and low protein-binding characteristics, peak drug levels may reach high $\mu \mathrm{M}$ to low mM concentrations. ${ }^{16,47}$ METH levels in gingival tissue, however, are not yet known.

Most studies investigating METH cytotoxicity have been performed using neuronal cells, and it has been suggested that METH-induced release of dopamine from vesicles to cytosolic and extracellular spaces, with resultant free radical formation, may be an important factor in METH-induced neurotoxicity. ${ }^{45}$ However, METH may cause toxicity independent of dopamine and have a more general toxic process. Results of in vitro and in vivo experiments suggested that METH can cause apoptotic neuronal cell death. ${ }^{44,45,48,49,50,51,52,53,54}$ For example, Genc et al., in work using rat oligodendrocytes, suggested that METH upregulated the pro-apoptotic genes bax and DP5, and studies by Israeli et al. showed that METH neurotoxicity involves a p53-inducible gene that promotes apoptosis. ${ }^{43,45}$ Other studies have suggested roles for superoxide radicals, cytokines, caspase activation, or temperature in METH cytotoxicity. $55,56,57,58,59,60,61$

The specific mechanism(s) of METH-induced cytotoxicity in gingival fibroblasts are unknown and await further study. It is likely that complex interactions between cells and other factors which affect cell behavior, such as extracellular matrix composition, may be involved in METH cytotoxicity in vivo. However, toxic effects of METH on human gingival fibroblasts, as shown in the present study, could compromise their synthetic ability and their involvement in periodontal healing, after the tissue destruction associated with chronic inflammation. 
In this study the effects of METH on matrix metalloproteinases (MMPs) were studied. MMPs comprise a large family of proteolytic enzymes containing a zinc-binding catalytic domain and act to degrade components of the extracellular matrix. ${ }^{62,63}$ The expression of different MMPs may be upregulated in pathological conditions such as inflammation and tumor invasion. In the context of oral diseases, MMPs are suggested to play an important role in the tissue destruction caused by the chronic inflammation of periodontitis. ${ }^{64} \mathrm{MMP}$ amounts and activities are significantly higher in gingival tissue and gingival crevicular fluid of periodontitis patients than in healthy subjects, and elevated MMP activity can also contribute to the metastasis of oral cancer. ${ }^{26,65,66}$ Ongoing elevated production/activity of MMPs by tumor and tumor-associated cells, and by host cells following stimulation by periodontopathogens, contributes to tissue destruction in these diseases. ${ }^{62}$ For example, MMP-2 and MMP-9 (also known as $72 \mathrm{kDa}$ and $92 \mathrm{kDa}$ type IV collagenases or gelatinase A and gelatinase B, respectively) are upregulated in periodontitis patients. ${ }^{67,68,69}$ The gelatinases can cleave several substrates, including collagen types IV and V, laminin, and chondroitin sulfate proteoglycan. MMP-2 and MMP-9 are also associated with the malignant phenotype of tumor cells due to their ability to degrade type IV collagen which is a major component of basement membranes. ${ }^{70}$ These MMPs are localized to the leading edges during normal and neoplastic cell invasion and migration and are believed to play a critical role in tumor invasiveness and metastasis. ${ }^{71}$ For example, elevated MMP-2 and MMP-9 activities have been shown to be important in metastatic cancers such as ovarian carcinoma and oral cancers. $^{26,72,73,74}$

In health, MMPs are involved in normal remodeling and turnover of periodontal tissues. ${ }^{62,63}$ MMP expression and activity are tightly regulated and are subject to several layers of control in transcription and post-translational activation. ${ }^{75}$ For example, most MMPs are secreted in latent form. The exact activation mechanisms of these MMP proenzymes are not well understood. In vitro, pro-MMPs are activated by treatment with proteinases, mercurial compounds, chaotropic agents, $\mathrm{HOCl}$, low $\mathrm{pH}$, or heat. ${ }^{76,77,78,79,80}$ In vivo, activation may occur through cleavage by other MMPs or by serine proteases such as trypsin or plasmin. ${ }^{81,82}$ In addition, MMP activity is regulated by endogenous specific inhibitors, the tissue inhibitors of metalloproteinases (TIMPs), and the tissue plasminogen/plasmin system. ${ }^{62,63,83,84}$ The balance between MMPs and TIMPs plays an important role in maintaining the integrity of healthy tissues. Together, MMPs and TIMPs modulate functional and structural remodeling of the cellular milieu through cleavage of extracellular matrix (ECM) molecules, bioavailability of growth factors and cytokines, and shedding of membrane receptors. ${ }^{85,86,87}$ A disturbed balance of MMPs and TIMPs can be found in various pathologic conditions. ${ }^{88,89,90}$ Four closely-related TIMPs have been discovered in different species, designated TIMP-1, $-2,-3$, and $-4 .^{91,92,93,94,95}$ In the ECM, TIMPs form non-covalent 1:1 stoichiometric complexes with MMPs. Almost all MMPs can be inhibited by all four TIMPs, although differences in binding affinity have been reported. ${ }^{96}$ MMPs are produced by the major cell types in human periodontal tissue, including neutrophils, macrophages, epithelial cells, and fibroblasts. ${ }^{97}$ Fibroblasts are a major constituent of the gingival connective tissue. They produce structural 
connective tissue proteins and glycosaminoglycans, cytokines and mediators that promote chronic inflammation, as well as MMPs and TIMPs. ${ }^{98,99}$

In this study, the effects of METH on human gingival fibroblast production of MMP-2 and MMP-9, TIMP-1 and TIMP-2, and MMP:TIMP complexes were determined. The fibroblasts constitutively produced MMP-2, TIMP-1, and TIMP-2. MMP-9 was not constitutively produced by these cells. These findings are consistent with the observation that human gingival fibroblasts used in another study produced MMP-2, TIMP-1, and TIMP-2, but not MMP-9. ${ }^{100}$ While a study by Westerlund et al. showed that neutrophils were the major source of MMP-9 in periodontitis gingiva, others found that rat gingival fibroblasts produce MMP-9 constitutively, and in response to stimulation by TNF ${ }^{101,102}$ MMP-9 can also be produced by human and mouse dermal and lung fibroblasts, constitutively or in response to factors such as mast cell interaction, tumor cell interaction (via TNF $\alpha$, TGF $\beta$ and EGF) and thrombin. ${ }^{103,104,105,106}$ When expressed by fibroblasts, MMP-9 levels are usually low, compared to MMP-2. ${ }^{107}$ MMP-2/TIMP complexes were produced constitutively (MMP-2:TIMP-2 > MMP-2:TIMP-1). While there was no detectable MMP-9 production, the possibility existed that MMP-9 might be present in TIMP complexes that were not recognized by the MMP-9 assay, which has no cross-reactivity with TIMPs 1-4. However, there was no detectable constitutive production of MMP-9:TIMP-1 or MMP-9:TIMP-2 complexes. Approximately 25\% constitutively-produced MMP-2 was complexed with TIMP-1 orTIMP-2 under these conditions, as measured with these ELISA systems.

There was no significant effect of METH on MMP-2, TIMP-1, TIMP-2, or MMP2:TIMP complex protein levels, and METH had no significant effect on $\%$ complexed MMP-2 protein. Exposure to METH also did not induce detectable levels of MMP-9 or MMP-9/TIMP complexes. The lack of effect of METH on amounts of MMP-2 and TIMP-2 produced by the cells used in this study is in contrast to studies by Mizoguchi et al. on the effects of METH on rat neural tissue. ${ }^{40,108}$ They reported that repeated METH treatment increased MMP-2 levels in rat brain frontal cortex and nucleus accumbens, as well as MMP-9 levels and activity. MMP-2 and -9 expression induced by METH in these tissues was localized to neuronal and glial cells. Repeated METH treatment also increased TIMP-2 levels in rat brain frontal cortex, localized to neuronal cells.

In addition to MMP-2 protein, the effects of METH on MMP-2 activity were also determined. The assay used in this study detected endogenous levels of active MMP-2, or the total levels of MMP-2 (endogenous active + pro-MMP-2). In order to measure the total MMP-2 content, MMP-2 in its inactive pro form was activated using paminophenylmercuric acetate (APMA). Endogenous active MMP-2 (i.e. MMP-2 secreted in the active form) was detected in samples without APMA treatment. METH at $1 \times 10^{-5} \mathrm{M}$ increased total (endogenous active + APMA-activated) MMP-2 activity by approximately $50 \%$, compared to control, and significantly increased APMA-activated MMP-2 activity attributable to pro-MMP-2. This is consistent with another study which showed that repeated METH administration increased MMP-2 activity in rat brain, attributable to pro-MMP-2 and did not increase endogenous MMP-2 activity. ${ }^{40}$ In the 
present study, while there were low levels (generally $<10 \%$ ) of detectable endogenous active MMP-2, METH had no effect on this.

Total MMP-2 protein as well as TIMPS, MMP/TIMP complexes and \% complexed MMP-2) were not significantly affected by METH, yet MMP-2 activity was increased by exposure to $1 \times 10^{-5} \mathrm{M}$ METH. This suggested that METH may affect MMP2 post-transcriptionally, perhaps increasing activation of pro-MMP-2, rather than affecting MMP-2 protein levels. Because METH did not significantly affect TIMPs, MMP/TIMP complexes and \% complexed MMP-2, the increased activity was likely not due to changes in the levels of MMP inhibitors. (As noted above, the lack of effect of METH on gingival fibroblast TIMP-2 production is in contrast to its stimulation of rat neuronal TIMP-2). ${ }^{40}$ Therefore, the question was asked whether METH directly affected MMP-2 activation. In order to determine whether METH directly activated MMP-2 or enhanced APMA activation, pro-MMP-2 (standard from MMP-2 activity kit) was treated with $\mathrm{METH} \pm \mathrm{APMA}$ and assayed for activity. The results suggested that METH may directly activate MMP-2 and enhance APMA activation of free pro-MMP-2.

Itoh et al. have investigated the mechanism of activation of pro-MMP-2 by APMA. ${ }^{109}$ Pro-MMP-2 consists of a propeptide domain, a catalytic domain, and a Cterminal domain. ${ }^{110}$ Latency of pro-MMP-2 is maintained through the co-ordination of the $\mathrm{Zn}$ atom at the active site and the SH group of the cysteine residue in a highly conserved sequence of the propeptide domain. ${ }^{76,77}$ Pro-MMP-2 is readily activated in vitro by APMA. Itoh et al. have suggested that APMA perturbs the pro-MMP-2 molecule, as they showed for the activation of pro-MMP-3. ${ }^{111}$ The conformational changes in pro-MMP-2 subsequently disrupt the Cys-Zn interaction and exposes the active site.

Only free (non-TIMP-complexed) pro-MMP-2 expresses full activity upon activation by APMA. However, formation of the pro-MMP-2-TIMP-2 complex does not prevent its partial activation by APMA; the activated complex has enzymic activity equivalent to approximately 10\% of free MMP-2. ${ }^{111,112,113,114,115,116}$ Among the MMPs, pro-MMP-2 is unique in its ability to bind TIMPS. All other MMPs must be in their active form to bind TIMPs. ${ }^{117}$

In their investigation of the mechanism of activation of pro-MMP-2 by APMA, Itoh et al. used isolated pro-MMP-2-TIMP-2 complexes. They showed that treatment of this complex with APMA rearranges the interaction between TIMP-2 and pro-MMP-2 and that the N-terminal domain of TIMP-2 reacts with the catalytic site of pro-MMP-2 (Figure 11). Because the active site is then tightly blocked by TIMP, this complex remains proteolytically inactive. Addition of active MMP-2 or MMP-3 can cleave the propeptde, but the complex remains inactive. On the other hand, addition of an active MMP such as MMP-2 or MMP-3 to the pro-MMP-2-TIMP-2 complex (before addition of APMA) can bind and block the N-terminal domain of the TIMP-2 molecule that is bound to pro-MMP-2, forming a ternary complex. Subsequent addition of APMA causes conformational changes that break the $\mathrm{Zn}$-Cys interaction. The ternary complex is proteolytically active because $\mathrm{N}$-terminal domain of TIMP has been previously blocked 

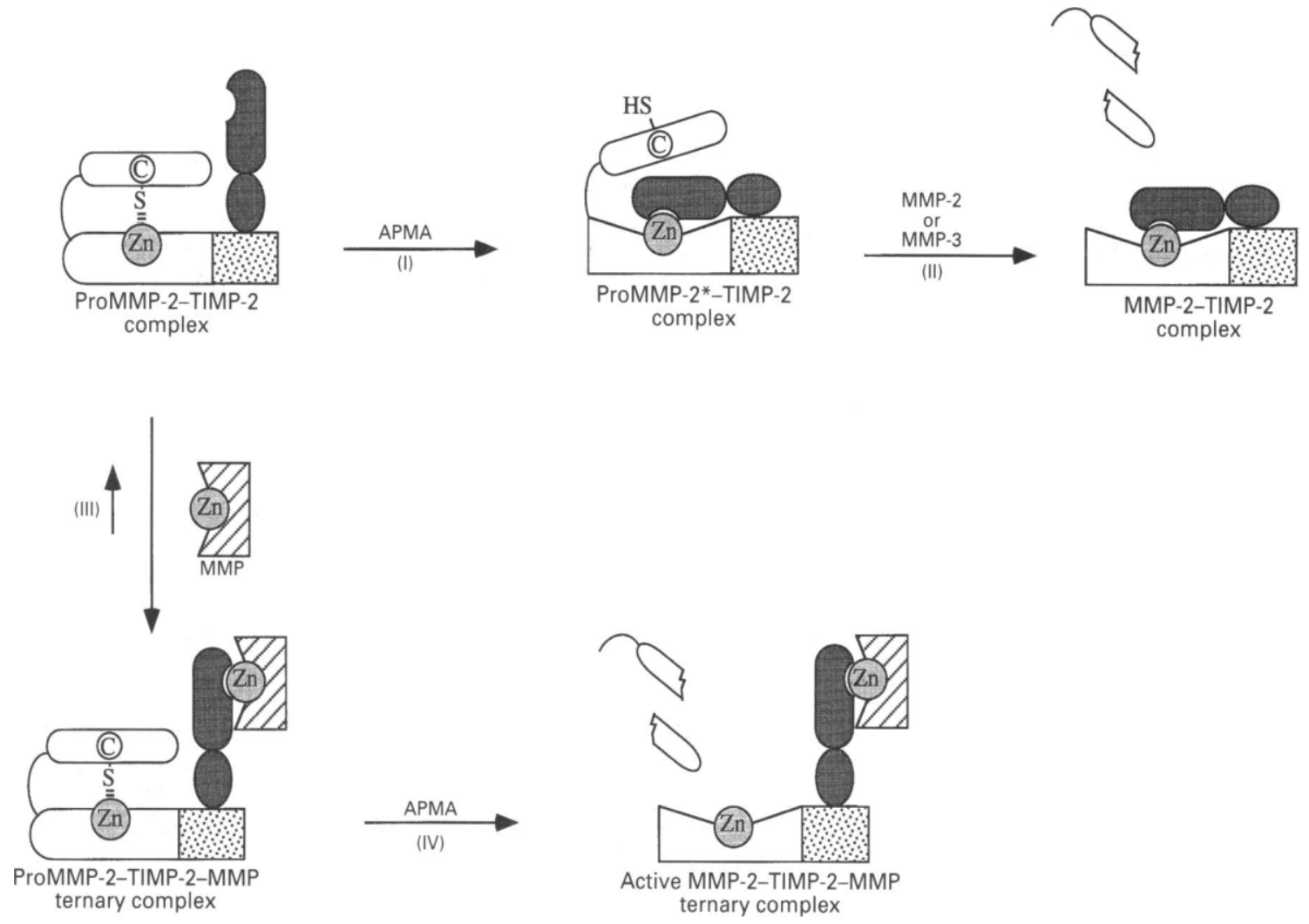

Figure 11. Proposed Mechanism of Activation of the Pro-MMP-2:TIMP-2 Complex by APMA 
(by the added, active MMP) and cannot bind to the active site of the pro-MMP-2 molecule (Figure 11). The level of MMP-2 activity attained depends upon the amount of active MMP-2 added prior to the addition of APMA. Therefore, Itoh et al. have shown that the level of active MMPs can influence MMP-2 activity. ${ }^{109}$

Our results show that METH can directly increase enzymatic activity of active MMP-2, and can also potentiate activation of pro-MMP-2 by APMA. The mechanisms for these effects remain to be investigated. A possible mechanism for direct increase in activity of active MMP-2 could be a METH-induced conformational change in MMP-2 that affects the active site and increases activity. It has been suggested that METH may cause a conformational change in another protein, vesicular monoamine transporter-2, in rats. ${ }^{118}$ In a similar vein, METH may also potentiate the conformational perturbations caused by APMA, or interact with and make the Zn-Cys interaction of pro-MMP-2 less stable, resulting in increased activity. While this may at least partially account for the METH-induced increase in MMP-2 activity in cell culture supernatants, it remains to be investigated. A recent search of the literature revealed no information on the ability of METH to directly disrupt the interaction of $\mathrm{Zn}^{2+}$ with other molecules.

As noted above, Itoh et al. have shown that the levels of other active MMPs can influence MMP-2 activity. In the present study, METH caused some increase in MMP-1 at $1 \times 10^{-5} \mathrm{M}$ and $1 \times 10^{-6} \mathrm{M}$, but these increases were not statistically significant (data not shown). [MMP-2 activity was increased at METH concentrations $\geq 5 \times 10^{-5} \mathrm{M}$ (statistically significant at $1 \times 10^{-5} \mathrm{M}$ only)]. METH was shown by others to increase MMP-1 production by mixed human neuron/astrocyte cultures. ${ }^{119}$ We found that METH also increased MMP-3 levels, but at concentrations higher than which an effect was seen on MMP-2 activity ( $\geq 1 \times 10^{-4} \mathrm{M}$ ) (data not shown). This suggests that METH could increase MMP-2 activity of gingival fibroblasts by increasing MMP-1, or possibly MMP3 levels, but this remains to be shown.

Another question remaining is the influence of the tissue plasminogen/plasmin system. In vivo, plasminogen activators, including urokinase-type plasminogen activator (uPA) and tissue plasminogen activator (tPA), convert plasminogen into plasmin, which then converts latent MMPs into their active forms (Vassalli et al.,1991). ${ }^{120}$ Interestingly, Xiao et al. reported that $\mathrm{tPA}$ levels in gingival crevicular fluid are correlated with the severity of periodontal conditions, suggesting that the plasminogen activator system plays a significant role in connective tissue destruction. ${ }^{121}$ METH was shown to increase uPA in human brain cells, but this is unknown for gingival fibroblasts. ${ }^{112}$

Generally, Pro-MMP-2 is resistant to activation by serine proteases alone, and in vivo, MMP-2 activation is mediated by membrane bound MMP (MT-MMP). ${ }^{112,122}$ In this instance, pro-MMP-2 activation by MT1-MMP (MMP-14) depends on low levels of TIMP-2, which binds to pro-MMP-2 and forms a ternary complex with MT1-MMP. ${ }^{71}$ Another MT-MMP then cleaves the bound MMP-2 and activates it. High concentrations of TIMP-2 can prevent pro-MMP-2 activation because it inhibits MT1-MMP. 
Most MT-MMPs (MT1-, MT2-, MT3-, MT5-, and MT6-MMPs) can also activate pro-MMP-2. Several serine proteases can act in concert with MT1-MMP to activate proMMP-2. ${ }^{123}$ However, work by others has suggested that pro-MMP-2 can be activated independently of MT-MMP. Tiranathanagul T et al. showed that bacterial LPS can activate pro-MMP-2 via a serine protease dependent pathway in periodontal ligament cells and human breast adenocarcinoma cells ${ }^{124}$ and Nguyen et al. showed that activated protein $\mathrm{C}$ directly activated pro-MMP-2 in endotherial cells. ${ }^{125}$ In addition, latent MT1MMP can be shed from the cell membrane, activated via the uPA cascade, leading to activation of pro-MMP-2. ${ }^{126}$

The work in the present study has shown that METH can increase MMP-2 activity in vitro. METH did not affect protein levels of MMP-2 or its inhibitors TIMP-1 or TIMP-2. However, we showed that METH can increase the activity of active MMP-2, and potentiate APMA-activation of pro-MMP-2. This may occur through METH-induced conformational perturbations or disruption of the $\mathrm{Zn}$-Cys interaction important in maintaining the latency of this enzyme, as well as the increase in other MMPs that can help activate pro-MMP-2. In vivo, METH may be able to have similar actions on proMMP-2 activation, but other factors could contribute to its activation. These include plasminogen activators well as MT-MMPs.

As mentioned earlier current literature show no published studies on the effects of METH on specific oral tissue cells and their activities. The effect of METH on gingival fibroblast MMP production, activity and regulation were unknown. Up-regulation of MMP-2 activity in vitro by METH on gingival fibroblast is an interesting finding. Whether this effect can be seen in vivo as well is a subject for future studies. However this highlights the possible role of METH in vitro in increasing the severity of periodontal destruction and tumor metastasis. It also raises questions about the mechanisms that might be at play when METH comes into contact with oral tissue cells. Further studies would be needed to explain their mechanisms and to understand how this drug might be complicating and contributing to oral tissue destruction when tissues are inflamed as in chronic periodontal disease. 


\section{LIST OF REFERENCES}

1. Shaner JW. Caries associated with METH abuse. J Mich Dent Assoc 2002; 84:4247.

2. Hamamoto DT, Rhodus NL. METH abuse and dentistry. Oral Dis 2009; 15:2737.

3. Substance Abuse and Mental Health Services Administration. National Survey on Drug Use and Health. http://oas.samhsa.gov/nsduh.htm (accessed 2009 Jan 18).

4. Centers for Disease Control and Prevention. Youth risk behavior surveillanceUnited States, 2001.

http://www.cdc.gov/mmwr/preview/mmwrhtml/ss5104a1.htm (accessed 2009 Jan $18)$.

5. Hoffman BB. Catecholamines, sympathomimetic drugs, and adrenergic receptor antagonists. In: Hardman JG, Limbird LE, eds. Goodman and Gilman's the pharmacological basis of therapeutics. 10th ed. New York: McGraw-Hill; 2001: 215-260.

6. Lacey CF, Goldman MP, Lance LL, Ingrim NB. Drug information handbook. 13th ed. Hudson, OH: Lexi-Comp; 2005: 971-972.

7. Lee CYS, Heffez LB, Mohammadi H. Crystal METH abuse: a concern to oral and maxillofacial surgeons. J Oral Maxillofac Surg 1992; 50:1052-1054.

8. American Dental Association. METH use and oral health. J Am Dent Assoc 2005; 136:1491.

9. Office of National Drug Control Policy. METH. http://whitehousedrugpolicy.org/publications/pdf/ncj197534.pdf (accessed 2009 Jan 27).

10. Lineberry TW, Bostwick JM. METH abuse: a perfect storm of complications. Mayo Clin Proc 2006; 81:77-84.

11. Rhodus NL, Little JW. METH abuse and "meth mouth." Northwest Dent 2005; 84:29-37.

12. Scandling J, Spital A. Amphetamine associated myoglobinuric renal failure. South Med J 1982; 75:237-240. 
13. Williams F, Turner T. Adrenergic pharmacology. In: Golan DE, Taschijian AH, Armstrong EJ, Galanter JM, Armstrong AW, Arnaout RA, Rose HS, eds Principles of pharmacology. The pathophysiologic basis of drug therapy. Baltimore: Lippincott Williams and Wilkins; 2005; 107-117.

14. Olkkola KT, Ahonen J. Drug interactions. Curr Opin Anaesthesiol 2001; 14:411416.

15. Alberta Alcohol and Drug Abuse Commission. Amphetamines. http://corp.aadac.com/content/corporate/other_drugs/amphetamines beyond_abcs .pdf (accessed 2009 Jan 18).

16. Schepers RJ, Oyler JM, Joseph RE, Jr Cone EJ, Moolchan ET, Huestis MA. METH and amphetamine pharmacokinetics in oral fluid and plasma after controlled oral METH administration to human volunteers. Clin Chem 2003; 49:121-132.

17. Jones KD. Viewpoint: spotting meth mouth. http://www.ada.org/prof/resources/\%20pubs/a\%20danews/a\%20danewsar\% $\% 20 t \%$ 20icle.asp?\%20articleid=1517 (accessed 2009 Feb 13).

18. Saini TS, Edwards PC, Kimmes NS, Carroll LR, Shaner JW, Dowd FJ. Etiology of xerostomia and dental caries among METH abusers. Oral Health Prev Dent 2005; 3:189-195.

19. Navarro M, Pichini S, Farre M, Jordi O, Roset PN. Usefulness of saliva for measurement of 3,4- methylenedioxyMETH and its metabolites: correlation with plasma drug concentrations and effect of salivary pH. Clin Chem 2001; 47:17881795.

20. Lineberry TW, Bostwick JM. METH abuse: a perfect storm of complications. Mayo Clin Proc 2006; 81:77-84.

21. Curtis EK. Meth mouth: a review of METH abuse and its oral manifestations. Gen Dent 2006; 54:125-129

22. Chen D, Wang Q, Ma ZW, Chen FM, Chen Y, Xie GY, Wang QT, Wu ZF. MMP-2, MMP-9 and TIMP-2 gene polymorphisms in Chinese patients with generalized aggressive periodontitis. J Clin Periodontol 2007; 34:384-389.

23. Patel BP, Shah SV, Shukla SN, Shah PM, Patel PS. Clinical significance of MMP-2 and MMP-9 in patients with oral cancer. Head Neck 2007; 29:564-572. 
24. Sodek J, Overall CM. Matrix metalloproteinases in periodontal tissue emodelling. Matrix Suppl 1992; 1:352-362.

25. Wagner S. Methamphetamine use and oral health. http://www.ada.org/public/topics/methmouth.asp. (accessed 2009 March 12).

26. Reynolds JJ. Collagenases and tissue inhibitors of metalloproteinases: a functional balance in tissue degradation. Oral Dis 1996; 2:70-76.

27. Pozo P. Longitudinal analysis of metalloproteinases, tissue inhibitors of metalloproteinases and clinical parameters in gingival crevicular fluid from periodontitis-affected patients. J Periodont Res 2005; 40:199-207.

28. Woodward JK, Holen I, Coleman RE, Buttle DJ. The roles of proteolytic enzymes in the development of tumour-induced bone disease in breast and prostate cancer. Bone 2007; 41:912-927.

29. Pussinen PJ, Paju S, Mantyla P, Sorsa T. Serum microbial- and host-derived markers of periodontal diseases: A review. Curr Med Chem 2007; 14:2402-2412.

30 auf dem Keller U, Doucet A, Overall CM. Protease research in the era of systems biology. Biol Chem 2007; 388:1159-1162.

31. Ra HJ, Parks WC. Control of matrix metalloproteinase catalytic activity. Matrix Biol 2007; 26:587-596.

32. Shindoh M, Higashino F, Kaya M, Yasuda M, Funaoka K, Hanzawa M, Hida K, Kohgo T, Amemiya A, Yoshida K, Fujinaga K. Correlated expression of matrix metalloproteinases and ets family transcription factor E1A-F in invasive oral squamous-cell-carcinoma-derived cell lines. Am J Pathol 1996 ;148:693-700.

33. Makela M, Uitto V-J, Larjava H. Matrix metalloproteinases (MMP-2 and MMP9) of the oral cavity: Cellular origin and relationship to periodontal status. J Dent Res 1996; 75:1397-1406.

34. Ryan ME, Ramamurthy NS, Golub LM. Matrix metalloproteinases and their inhibition in periodontal disease. Curr Opin Periodontol 1996; 3:85-96.

35. Ejeil A-L, Igondjo-Tchen S, Ghomrasseni S, Pellat B, Godeau G, Gogly B. Expression of matrix metalloproteinases (MMPs) and tissue inhibitors of metalloproteinases (TIMPs) in healthy and diseased human gingiva. J Periodontol 2003; 74:188-195. 
36. Nelson AR, Fingleton B, Rothenberg ML, Matrisian LM. Matrix metalloproteinases: biologic activity and clinical implications. J Clin Oncol 2000; 18:1135-1149.

37. Moser TL, Young TN, Rodriguez GC. Pizzo SV, Bast, RC, Stack MS. Secretion of extracellular matrix-degrading proteinases is increased in epithelial ovarian carcinoma. Int J Cancer 1994; 56:552-559.

38. Hida K, Shindoh M, Yoshida K, Kudoh A, Furaoka K, Kohgo T, Fujinaga K, Totsuka Y. Expression of E1AF, an ets-family transcription factor, is correlated with the invasive phenotype of oral squamous cell carcinoma. Oral Oncol 1997 ;33:426-430.

39. Gao ZB, Duan YQ, Zhang L, Chen DW, Ding PT. Expression of matrix metalloproteinase 2 and its tissue inhibitor in oral squamous cell carcinoma. Int $\mathbf{J}$ Mol Med 2005; 16:599-603.

40. Mizoguchi H, Yamada K, Mouri A, Niwa M, Mizuno T, Noda Y, Nitta A, Itohara S, Banno Y, Nabeshima T. Role of matrix metalloproteinase and tissue inhibitor of MMP in methamphetamine-induced behavioral sensitization and reward: implications for dopamine receptor down-regulation and dopamine release. $\mathrm{J}$ Neurochem 2007; 102:1548-1560.

41. Lowry OH, Rosebrough NJ, Farr L, Randall RJ. Protein measurement with the folin phenol reagent. J Biol Chem 1951; 193:265-275.

42. VI, Eagle H. Measurement of cell growth in tissue culture with a phenol reagent (Folin-Ciocalteau). Proc Soc Exp Biol Med 1956; 91:305-307.

43. Israeli D, Tessler E, Haupt Y. A novel p53-inducible gene PAG608 encodes a nuclear zinc finger protein whose overexpression promotes apoptosis. EMBO J 1997; 16:4384-4392 .

44. Deng X, Cai N, McCoy M, Chen W, Trush M, Cadet J. Methamphetamine induces apoptosis in an immortalized rat striatal cell line by activating the mitochondrial cell death pathway. Neuropharmacol 2002; 42:837-845

45. Genc K, Genc S, Kizildag S, Sonmez U, Yilmaz O, Tugyan K, Ergur B, Sonmez A, Buldan Z. Methamphetamine induces oligodendroglial cell death in vitro. Brain Res 2003; 982:125-130.

46. Legan Z, Tipton D, Dabbous M. Fibrogenic effects of methamphetamine on LPSstimulated IL-1 $\beta$ production by human monocytes. J Dent Res 2009; 88 (Special Issue A) Abstr. \#1363. 
47. Reese EA, Bunzow JR, Arttamangkul S, Sonders MS, Grandy DK. Trace amineassociated receptor 1 displays species-dependent stereoselectivity for isomers of methamphetamine, amphetamine, and para-hydroxyamphetamine. J Pharmacol Exp Ther 2007; 321:178-86.

48. Cadet J, Ordonez S, Ordonez J. Methamphetamine induces apoptosis in immortalized neural cells: protection by the proto-oncogene bel-2. Synapse 1997; 25:176-184

49. Choi HJ, Yoo, TM, Chung SY, Yang SY, Kim JY, Ha ES, Hqang O. Methamphetamine-induced apoptosis in a CNS-derived catecholaminergic cell line. Mol Cells 2002; 13:221-227.

50. Davidson C, Gow A, Lee T, Ellinwood E. Methamphetamine neurotoxicity: necrotic and apoptotic mechanisms and relevance to human abuse and treatment. Brain Res Rev 2001; 36:1-22

51. Deng X, Wang Y, Chou J, Cadet J. Methamphetamine causes widespread apoptosis in the mouse brain: evidence from suing an improved TUNEL histochemical method. Brain Res Mol Brain Res 2001; 93:64-69.

52. Stumm G, Schlegel J, Schafer T, Wurz C, Mennel HD, Kreig JC, Vedder H. Amphetamines induce apoptosis and regulation of bcl-x splice variants in neocortical neurons. FASEB J 1999; 13:1065-1072.

53. Asanuma M, Miyazaki I, Higashi Y Diaz-Corrales FJ, Shimizu M, Miyoshi K, Ogawa N. Suppression of p53-activated gene PAG608, attenuates methamphetamine-induced neurotoxicity Neurosci Lett 2007; 414:263-267.

54. Jayanthi S, Deng X, Bordelon M., McCoy M, Cadet J. Methamphetamine causes differential regulation of pro-death and anti-death Bcl-2 genes in the mouse neocortex. FASEB J 2001; 15:1745-1752.

55. Cadet J, Sheng P, Ali S, Rothman R, Carlson E, Epstein C. Attenuation of methamphetamine-induced neurotoxicity in copper/zinc superoxide dismutase transgenic mice. J Neurochem 1994; 62: 380-383.

56. Hirata H, Cadet J. p53-knockout mice are protected against the long-term effects of methamphetamine on dopaminergic terminals and cell bodies. J Neurochem 1997; 69:780-790.

57. Deng X, Cadet J. Methamphetamine-induced apoptosis is attenuated in the striata of copper-zinc superoxide dismutase transgenic mice. Brain Res Mol Brain Res 2000; 83: 121-124. 
58. Cubells J, Raport S, Rajendran G, Sulzer D. Methamphetamine neurotoxicity involves vacuolation of endocytic organelles and dopamine-dependent intracellular oxidative stress. J Neurosci 1994; 14: 2260-2271.

59. Cadet J, Brannock C. Free radicals and the pathobiology of brain dopamine systems. Neurochem Int 1998; 32: 117-131.

60. Ladenheim B, Krasnova I, Deng X, Oyler JM, Polettini A, Moran TH, Huestis MA, Cadet JL. Methamphetamine induced neurotoxicity is attenuated in transgenic mice with a null mutation for interleukin-6. Mol Pharmacol 2000; 2058: $1247-1256$.

61. Yuan J, Callahan B, McCann UD, Ricaurte G. Evidence against an essential role of endogenous brain dopamine in methamphetamine-induced dopaminergic neurotoxicity. J Neurochem 2001; 77:1338-1347.

62. Birkedal-Hansen H. Role of matrix metalloproteinases in human periodontal diseases. J Periodontol 1993; 64:474-484.

63. Sorsa T, Tjaderhane L, Salo T. Matrix metalloproteinases (MMPs) in oral diseases. Oral Dis 2004; 10:311-318.

64. Chen D, Wang Q, Ma ZW, Chen FM, Chen Y, Xie GY, Wang QT, Wu ZF. MMP-2, MMP-9 and TIMP-2 gene polymorphisms in Chinese patients with generalized aggressive periodontitis. J Clin Periodontol 2007; 34:384-389.

65. Soell M, Elkaim R, Tenenbaum H, Cathepsin C. Matrix metalloproteinases, and their tissue inhibitors in gingiva and gingival crevicular fluid from periodontitisaffected patients. J Dent Res 2002; 81:174-178.

66. Uitto VJ, Overall CM, McCulloch C. Proteolytic host cell enzymes in gingival crevice fluid. Periodontol 2000 2003; 31:77-104.

67. Makela M, Uitto V-J, Larjava H. Matrix metalloproteinases (MMP-2 and MMP9) of the oral cavity: Cellular origin and relationship to periodontal status. J Dent Res 1996; 75:1397-1406.

68. Ryan ME, Ramamurthy NS, Golub LM. Matrix metalloproteinases and their inhibition in periodontal disease. Curr Opin Periodontol 1996; 3:85-96.

69. Ejeil A-L, Igondjo-Tchen S, Ghomrasseni S, Pellat B, Godeau G, Gogly B. Expression of matrix metalloproteinases (MMPs) and tissue inhibitors of metalloproteinases (TIMPs) in healthy and diseased human gingiva. J Periodontol 2003; 74:188-95. 
70. Nelson AR, Fingleton B, Rothenberg ML, Matrisian LM. Matrix metalloproteinases: biologic activity and clinical implications. J Clin Oncol 2000; 18:1135-1149.

71. Hubbard N, Lim D, Erickson K. Conjugated linoleic acid alters matrix metalloproteinases of metastatic mouse mammary tumor cells. J Nutr 2007; 137:1423-1429.

72. Moser TL, Young TN, Rodriguez GC. Pizzo SV, Bast, RC, Stack MS. Secretion of extracellular matrix-degrading proteinases is increased in epithelial ovarian carcinoma. Int J Cancer 1994; 56:552-559.

73. Horiuchi S, Yamamoto H, Min Y, Adachi Y, Itoh F, Imai K. Association of etsrelated transcriptional factor E1AF expression with tumour progression and overexpression of MMP-1 and matrilysin in human colorectal cancer. J Pathol $2003 ; 200: 568-576$

74. Gao ZB, Duan YQ, Zhang L, Chen DW, Ding PT. Expression of matrix metalloproteinase 2 and its tissue inhibitor in oral squamous cell carcinoma. Int $\mathrm{J}$ Mol Med 2005; 16:599-603.

75. Yan C, Boyd D. Regulation of matrix metalloproteinase gene expression. J Cell Physiol 2007; 211:19-26.

76. Springman EB, Angleton EL, Birkedal-Hansen H, Van Wart HE. Multiple modes of activation of latent human fibroblast collagenase: evidence for the role of a Cys 73 active-site zinc complex in latency and a "cysteine switch" mechanism for activation. Proc Natl Acad Sci USA 1990; 87:364-368.

77. Van Wart H, Birkedal-Hansen H. The cysteine switch: a principle of regulation of metalloproteinase activity with potential applicability to the entire matrix metalloproteinase gene family. Proc Natl Acad Sci USA 1990; 87:5578-5582.

78. Howard E, Bullen E, Banda M. Regulation of the autoactivation of human 72kDa progelatinase by tissue inhibitor of metalloproteinases-2. J Biol Chem 1991; 266:13064-13069.

79. Koklitis P, Murphy G, Sutton C, and Angal S. Purification of recombinant human prostromelysin. Studies on heat activation to give high-Mr and low-Mr active forms, and a comparison of recombinant with natural stromelysin activities. Biochem J 1991; 276:217-221.

80. Davis GE, Martin BM. A latent Mr 94,000 gelatin-degrading metalloprotease induced during differentiation of HL-60 promyelocytic leukemia cells: a member of the collagenase family of enzymes. Cancer Res 1990; 50:1113-1120. 
81. Crabbe T, O’Connell J, Smith B, Docherty A. Reciprocated matrix metalloproteinase activation: a process performed by interstitial collagenase and progelatinase A. Biochem 1994; 33:14419-14425.

82. Imai K, Yokohama Y, Nakanishi I, Ohuchi E, Fujii Y, Nakai N, Okada Y. Matrix metalloproteinase 7 (matrilysin) from human rectal carcinoma cells. Activation of the precursor, interactions with other matrix metalloproteinases and enzymic properties. J Biol Chem 1995; 270:6691-6697.

83. Wang X, Lee S, Arai K, Lee SR, Tsuji K, Rebeck GW, Lo EH. Lipoprotein receptor-mediated induction of matrix metalloproteinase by tissue plasminogen activator. Nat Med 2003; 9:1313-1317.

84. Wright J, Reichert J, Davis C, Harding J. Neural plasticity and the brain reninangiotensin system. Neurosci Biovehav Rev 2002; 26:529-552.

85. Yong V, Power C, Forsyth P, Edwards D. Metalloproteinases in biology and pathology of the nervous system. Nat Rev Neurosci 2001; 2:502511.

86. Sternlicht M, Werb Z. How matrix metalloproteinases regulate cell behavior. Annu Rev Cell Dev Biol 2001; 17:463-516.

87. Tsuruda T, Costello-Boerrigter LC, Burnett JC Jr. Matrix metalloproteinases: pathways of induction by bioactive molecules. Heart Fail Rev 2004; 9:53-61.

88. Verstappen J, Von den Hoff J. Tissue inhibitors of metalloproteinases (TIMPs): their biological functions and involvement in oral disease. J Dent Res 2006; 85:1074-1084.

89. Gomez D, Alonso D, Yoshiji H, Thorgeirsson U. Tissue inhibitors of metalloproteinases: structure, regulation and biological functions. Eur J Cell Biol 1997; 74:111-122.

90. Lambert E, Dasse E, Haye B, Petitfrere E. TIMPs as multifacial proteins. Crit Rev Oncol Hematol 2004; 49:187-198.

91. Blenis J, Hawkes SP. Transformation-sensitive protein associated with the cell substratum of chicken-embryo fibroblasts. Proc Natl AcadSci USA 1983; 80:770774.

92. Herron G, Banda M, Clark E, Gavrilovic J, Werb Z. Secretion of metalloproteinases by stimulated capillary endothelial cells. II. Expression of collagenase and stromelysin activities is regulated by endogenous inhibitors. J Biol Chem 1986; 261:2814-2818. 
93. Staskus P, Masiarz F, Pallanck L, Hawkes S. The 21-kDa protein is a transformation-sensitive metalloproteinase inhibitor ofchicken fibroblasts. J Biol Chem 1991; 266:449-454.

94. Pavloff N, Staskus P, Kishnani N, Hawkes S. A new inhibitor of metalloproteinases from chicken: ChIMP-3. A third member of the TIMP family. J Biol Chem 1992. 267:17321-17326.

95. Greene J, Wang M, Liu Y, Raymond L, Rosen C, Shi Y. Molecular cloning and haracterization of human tissue inhibitor of metalloproteinase 4. J Biol Chem 1996; 271:30375-30380.

96. Olson MW, Gervasi DC, Mobashery S, Fridman R (1997). Kinetic analysis of the binding of human matrix metalloproteinase-2 and -9 to tissue inhibitor of metalloproteinase (TIMP)-1 and TIMP-2. J Biol Chem 272:29975-29983.

97. Uitto VJ, Overall CM, McCulloch C. Proteolytic host cell enzymes in gingival crevice fluid. Periodontol 2000 2003; 31:77-104.

98. Hassell T. Tissues and cells of the periodontium. Periodontol 2000 1993; 3:9-38.

99. Takashiba S, Naruishi K, Murayama Y. Perspective of cytokine regulation for periodontal treatment: fibroblast biology. J Periodontol 2003; 74:103-110.

100. Bodet C, Andrian E, Tanabe S-I, Grenier D. Actinobacillus actinomycetemcomitans regulates matrix metalloproteinase, tissue inhibitors of matrix metalloproteinase, and plasmoinogen activator production by human gingival fibroblasts: a pivotal role in connective tissue destruction. J Cell Physiol 2007; 212:189-194.

101. Westerlund U, Ingman T, Lukinmaa P. Human neutrophil gelatinase and associated lipocalin in adult and localized juvenile periodontitis. J Dent Res 1996; 75:1553-1563.

102. Kim S-J, Chuung Y-K, Chung T-W, Kim JR, Moon SK, Kim CH, Park YG. Regulation of matrix metalloproteinase-9 expression between gingival fibroblast cells from old and young rats. Biochem Biophys Res Commun 2009; 378:152156.

103. Abel M, Vliagoftis H. Mast cell-fibroblast interactions induce matrix metalloproteinase-9 release from fibroblasts: role for IgE-mediated mast cell activation. J Immunol 2008; 180:3543-3550. 
104. Ramos C, Montano J, Garcia-Alvarez V, Ruiz V, Uhal BD, Selman M, Pardo A. Fibroblasts from idiopathic pulmonary fibrosis and normal lungs differ in growth rate, apoptosis, and tissue inhibitor of metalloproteinases expression. Am J Respir Cell Mol Biol 2001; 24:591-598.

105. Stuelton C, Ryfield S, Grany P, Karpova T, Stetler-Stevenson W, Roberts A. Breast cancer cells induce stromal fibroblast to express MMP-9 via secretion of TNF $\alpha$ and TGF $\beta$. J Cell Sci 2005; 118:2143-2153.

106. Wang L, Luo J, He S. Induction of MMP-9 release from human dermal fibroblasts by thrombin: involvement of JAK.STAT3 signaling pathway in MMP9 release. BMC Cell Biol 2007; 8:14-22.

107. Stuelton C, Ryfield S, Grany P, Karpova T, Stetler-Stevenson W, Roberts A. Breast cancer cells induce stromal fibroblast to express MMP-9 via secretion of TNF $\alpha$ and TGF $\beta$ J Cell Sci 2005; 118:2143-2153.

108. Mizoguchi H, Yamada K, Niwa M, Mouri A, Mizuno T, Noda Y, Nitta A, Itohara S, Banno Y, Nabeshima T. Reduction of methamphetamine-induced sensitization and reward in matrix metalloproteinase-2 and -9-deficient mice. $\mathrm{J}$ Neurochem 2007; 100:1579-1588.

109. Itoh Y, Binner S, Nagase H. Steps involved in activation of the complex of promatrix metalloproteinase 2 (progelatinase A) and tissue unhibitor of metalloproteinases (TIMP)-2 by 4-aminophenylmercuric acetate. Biochem $\mathrm{J}$ 1995; 308:645-651.

110. Collier IE, Wilhelm SM, Eisen AZ, Marmer BL, Grant GA, Seltzer JL, Kronberger A, He CS, Bauer EA, Goldberg GI. H-ras oncogene-transformed human bronchial epithelial cells (TBE-1) secrete a single metalloprotease capable of degrading basement membrane collagen. J Biol Chem 1988; 263:6579-6587.

111. Goldberg GI, Marmer BL, Grant GA, Eisen AZ, Wilhelm S, He CS. Human 72kilodalton type IV collagenase forms a complex with a tissue inhibitor of metalloproteases designated TIMP-2. Proc Natl Acad Sci USA 1989; 86:82078211.

112. Howard E, Banda M. Binding of tissue inhibitor of metalloproteinases 2 to two distinct sites on human $72-\mathrm{kDa}$ gelatinase. Identification of a stabilization site.J Biol Chem 1991; 266:17972-17977. 
113. Fridman R, Bird RE, Hoyhtya M, Oelkuct M, Komarek D, Liang CM, Berman ML, Liotta LA, Stetler-Stevenson WG, Fuerst TR. Expression of human recombinant $72 \mathrm{kDa}$ gelatinase and tissue inhibitor of metalloproteinase-2 (TIMP2): characterization of complex and free enzyme. J Biol Chem 1992; 267:1539815405 .

114. Howard E, Bullen E, Banda J. Regulation of the autoactivation of human 72-kDa progelatinase by tissue inhibitor of metalloproteinases-2. J Biol Chem 1991; 266:13064-13069.

115. Kleiner J, Unsworth E, Krutzsch H, Stetler-Stevenson W. Higher-order complex formation between the 72-kilodalton type IV collagenase and tissue inhibitor of metalloproteinases-2. Biochem 1992; 31:1665-1672.

116. Fridman R, Bird RE, Hoyhtya M, Oelkuct M, Komarek D, Liang CM, Berman ML, Liotta LA, Stetler-Stevenson WG, Fuerst TR. Expression of human recombinant $72 \mathrm{kDa}$ gelatinase and tissue inhibitor of metalloproteinase-2 (TIMP2): characterization of complex and free enzyme. Biochem J.1993; 15:411-416.

117. Murphy G, Willenbrock F, Ward R, Cockett M, Eaton D, Docherty A. The Cterminal domain of $72 \mathrm{kDa}$ gelatinase $\mathrm{A}$ is not required for catalysis, but is essential for membrane activation and modulates interactions with tissue inhibitors of metalloproteinases. Biochem J 1992; 283:637-641.

118. Brown J, Riddle E, Sandoval V, et al. A single methamphetamine administration rapdly decreases vesicular dopamine uptake. J Pharmacol Exp Ther 2002; 302:497-501.

119. Conant K, St Hillaire C, Anderson C, Galey D, Wang J, Nath A. Human immunodeficiency virus type 1 Tat and methamphetamine affect the release and activation of matrix-degrading proteinases. J Neurovirol 2004; 10:21-26.

120. Vassalli JD, Sappino AP, Belin D. The plasminogen activator/plasmin system. Clin Invest. 1991; 88:1067-1072.

121. Xiao Y, Li H, Bunn C, Bartold PM. The expression of plasminogen activator system in a rat model of periodontal wound healing. J Periodontol 2001; 72:849857.

122. Atkinson SJ, Crabbe T, Cowell S, Ward RV, Butler MJ, Sato H, Seiki M, Reynolds JJ, Murphy G. Intermolecular autolytic cleavage can contribute to the activation of progelatinase A by cell membranes. J Biol Chem 1995; 270:3047930485 . 
123. Shamamian P, Schwartz JD, Pocock BJ, Monea S, Whiting D, Marcus SG, Mignatti P. Activation of progelatinase A (MMP-2) by neutrophil elastase, cathepsin $\mathrm{G}$, and proteinase-3: a role for inflammatory cells in tumor invasion and angiogenesis. J Cell Physiol 2001; 189:197-206.

124. Tiranathanagul S, Yongchaitrakul T, Pattamapun K, Pavasant P. Actinobacillus actinomycetemcomitans lipopolysaccharide activates matrix metalloproteinase-2 and increases receptor activator of nuclear factor-kappaB ligand expression in human periodontal ligament cells. J Periodontol. 2004; 75:1647-1654.

125. Nguyen M, Arkell J, Jackson C. Activated protein C directly activates human endothelial gelatinase A. J Biol Chem 2000; 275:9095-9098.

126. Kazes I, Delarue F, Hagège J, Bouzhir-Sima L, Rondeau E, Sraer JD, Nguyen G. Soluble latent membrane-type 1 matrix metalloprotease secreted by human mesangial cells is activated by urokinase. Kidney Int. 1998; 54:1976-1984. 


\section{VITA}

Dr. Owais Ali Farooqi was born on May 11, 1975 in Karachi, Pakistan. He completed his Bachelors in Dental Surgery (BDS) from Karachi Medical and Dental College, University of Karachi in 1998. He worked as House Surgeon in Abbasi Shaheed Hospital from 1999-2000, and then as a Demonstrator (Clinical Instructor) in Fatima Jinnah Dental College from 2000 to 2002. While working as a faculty member, he was also enrolled in a Fellowship program in Operative Dentistry including Periodontics in the same institution. In September 2002, Dr. Farooqi migrated to Florida, United States and in March 2003, moved to Buffalo, NY for further education. He acquired Doctor of Dental Surgery (DDS) from State University of New York at Buffalo in 2006 and immediately afterwards joined the University of Tennessee Health Science Center as graduate student in Masters of Dental Science (MDS) and resident in Periodontics. 